\title{
Targeting the Inside of Cells with Biologicals: Chemicals as a Delivery Strategy
}

\author{
Andrea L. J. Marschall ${ }^{1}$ (D) \\ Accepted: 27 September 2021 / Published online: 27 October 2021 \\ (c) The Author(s) 2021
}

\begin{abstract}
Delivering macromolecules into the cytosol or nucleus is possible in vitro for DNA, RNA and proteins, but translation for clinical use has been limited. Therapeutic delivery of macromolecules into cells requires overcoming substantially higher barriers compared to the use of small molecule drugs or proteins in the extracellular space. Breakthroughs like DNA delivery for approved gene therapies and RNA delivery for silencing of genes (patisiran, ONPATTRO ${ }^{\circledR}$, Alnylam Pharmaceuticals, Cambridge, MA, USA) or for vaccination such as the RNA-based coronavirus disease 2019 (COVID-19) vaccines demonstrated the feasibility of using macromolecules inside cells for therapy. Chemical carriers are part of the reason why these novel RNA-based therapeutics possess sufficient efficacy for their clinical application. A clear advantage of synthetic chemicals as carriers for macromolecule delivery is their favourable properties with respect to production and storage compared to more bioinspired vehicles like viral vectors or more complex drugs like cellular therapies. If biologicals can be applied to intracellular targets, the druggable space is substantially broadened by circumventing the limited utility of small molecules for blocking protein-protein interactions and the limitation of protein-based drugs to the extracellular space. An in depth understanding of the macromolecular cargo types, carrier types and the cell biology of delivery is crucial for optimal application and further development of biologicals inside cells. Basic mechanistic principles of the molecular and cell biological aspects of cytosolic/nuclear delivery of macromolecules, with particular consideration of protein delivery, are reviewed here. The efficiency of macromolecule delivery and applications in research and therapy are highlighted.
\end{abstract}

\section{Key Points}

Classic drugs often only reach a small portion of all disease-relevant molecules.

Delivering DNA, RNA or proteins as drugs could substantially increase the possibilities for therapeutic intervention.

Delivery by chemical carriers allowed ground-breaking new therapies, including coronavirus disease 2019 (COVID-19) vaccines, but a thorough mechanistic understanding of the delivery methods is critical for successful application to biological molecules with different properties.

Andrea L. J. Marschall

andrea.marschall@gmx.net

1 Institute of Biochemistry, Biotechnology and Bioinformatics, Technische Universität Braunschweig, Brunswick, Germany

\section{Introduction}

Carriers for intracellular delivery can be categorized into compartments or molecules including lipids, polymers and inorganic carriers. Bioinspired compartments are for instance exosomes, viral vectors, bacterial ghosts or red blood cell ghosts, and bioinspired molecules as carriers include peptides or proteins [1, 2]. Employing a bacterial type 3 secretion system for delivery is another example of a bioinspired delivery strategy [3].

Different from bioinspired carriers, chemicals have certain advantages as drug carriers, including low production costs, potential for large scale production and often favourable properties for storage like high stability [4-6]. Especially if cargoes are delivered to many cells like whole tissues or organs, the ability to produce high quantities of carrier and cargo material for delivery can be decisive (for gene delivery based on adeno-associated viruses, doses in orders of magnitude up to $10^{14}$ vector genomes per kilogram body weight have been used [7]). Chemical carriers may reach higher loading capacities than viral vectors for 
cargoes like DNA [4, 6] and impose little or no size limits to nucleic acid cargoes. They are less immunogenic and considered safer than viral vectors $[4,8]$. Accessibility to rational design allows engineering carriers with specific properties required for individual steps in the delivery process.

Drugs based on non-viral nucleic acid delivery have been approved [9-14]. Cytosolic delivery of proteins, although practised in vitro [15-20], is not as advanced in its clinical utility, although targeting proteins directly allows interference in ways that are not possible with other approaches [21]. Besides circumventing the risk for insertional mutagenesis that is associated with DNA delivery [4], delivering proteins has the potential to individually target functions that are encoded in post-translational modifications, protein conformations, splice variants or different functional epitopes of a protein among other advantages of protein-protein interference [21]. Interfering with protein-protein interactions is a challenge for small molecules, and they are most suitable for targets with hydrophobic pockets. Protein-based drugs are most suitable for extracellular drugs. Considering targets with hydrophobic pockets or extracellular targets as "druggable", a majority of $80 \%$ of targets remain "undruggable" [22].

The possibility of drugging the intracellular space with macromolecules could substantially contribute to unlocking the many targets that are still considered undruggable. Chemical carriers based on lipids, polymers and inorganic carriers for macromolecule delivery will be reviewed here, with an emphasis on protein delivery.

\section{Cargoes}

\subsection{Comparison of DNA, RNA and Protein Delivery by Chemicals}

\subsubsection{Proteins Compared to Nucleic Acids for Cytosolic Delivery}

Cargo delivery can be divided into several distinct steps, including the association of cargo with carriers, contact of the complexes with the cell surface and uptake into cells by endocytosis, and endosomal release is usually required [23-26]. Although similar for some cargoes and carriers, there are distinct differences between the transfection of proteins and nucleic acids. In contrast to the negatively charged, comparably uniform physicochemical properties of nucleic acids, proteins are highly diverse in size, structure and charge distribution. A lipid-based carrier, for example, had to be optimized to allow delivery of an antibody [27]. A way to address the diversity of protein properties that complicates finding a carrier that fits all proteins is linking an entity to the protein that mediates association with the carrier. For example, fusion of a negatively charged entity to proteins has been shown to allow repurposing nucleic acidtransfection reagents for protein delivery $[18,28]$. Although proteins can be "anionized", this does not guarantee delivery by a cationic lipid-based carrier. Vice versa, a protein being cationic may not always be an obstacle to delivery [24]. For protein delivery with cationic lipid-based carriers, the ratios of surface areas and hydrophobic interactions of the cargo protein with the carrier were more important than charge ratios [24, 25]. To enhance attachment of proteins to carriers, natural polyphenols have been proposed as potential bridging ligands to a particular polymer-based carrier type $[29,30]$. In contrast to nucleic acids, the integrity of the protein's tertiary structure is essential for functionality. A critical difference between nucleic acid delivery and protein delivery is the presence or absence of amplification. While many nucleic acids benefit from inherent amplification effects, for most proteins, the number of molecules delivered is the actual amount that can be effective. An exception are enzymes, for which delivery of a single protein can result in many substrate molecules to be converted, i.e. an amplified effect from a low dose of delivered cargo.

\subsubsection{RNA Compared to DNA for Cytosolic/Nuclear Delivery}

The physicochemically more uniform nature of nucleic acids substantially simplifies the search for universally applicable carriers, but there are still some distinct differences between RNA and DNA with relevance to delivery [31]. Efficacies might be different depending on whether the cargo is plasmid DNA (pDNA) or short interfering RNA (siRNA), even with the same carrier type [32]. One of the reasons for this is the difference in barriers that need to be overcome by RNA or DNA. Cytosolic delivery is sufficient for RNA and many proteins, but the requirement for nuclear access is an additional barrier for DNA delivery [32, 33]. Further, complex stability differs depending on whether carriers associate with pDNA or RNA [32, 34]. The size of nucleic acids affects complex stability; if the electrostatic interaction with cationic carriers is limited because nucleic acids are small like siRNA, the stability of complexes is lower and complexes are more sensitive to dissociation by salts compared to larger nucleic acids like DNA $[32,34]$. The release of counter ions upon electrostatic interaction between carrier and cargo increases entropy. The more extensive electrostatic interactions of the larger DNA molecule can confer more stability to DNA-carrier complexes compared to RNA-carrier complexes [32]. High complex stability is advantageous before delivery to the final site of action, because it can have a 
protective effect on nucleic acids against degradation [35]. High stability with a resulting difficulty with regard to releasing the cargo from the carrier is often a disadvantage after the final site of action is reached [36] if release from the carrier is required for cargo function. The difference in size between DNA plasmids and short RNA oligonucleotides can also be relevant in the context of endocytic uptake. Large DNA molecules have to be condensed by polycations to smaller particles $[32,37,38]$, which are in a size range of particles that are taken up by endocytosis [39]. For comparison, DNA can be sized in the range of micrometres [32, $37,38]$, while the length of siRNA is in the range of a few nanometres [32, 40, 41].

\subsubsection{RNA and Proteins Compared as Potential Drugs}

An advantage that both proteins and RNA have in common is the lower risk they pose because they do not integrate into the genome [21, 42]. An advantage of the special case of delivering antibody encoding messenger RNA (mRNA) instead of delivering antibodies as recombinant proteins is the circumvention of aberrant post-translational modifications [43]. An advantage of mRNA-encoded versus recombinant antibodies as proteins is also their cost-effectiveness, ease of production and no requirement to optimize each sequence individually [43]. The therapeutic space could furthermore broaden due to the increased number of accessible targets if mRNA-encoded antibodies are applied to bind intracellular targets, which extracellularly applied antibodies usually cannot reach, including knockdown at the protein level by cytosolic intracellular antibodies (intrabodies) or endoplasmic reticulum (ER) retained intrabodies (ER intrabodies) $[21,44]$.

\subsubsection{Macromolecules in the Absence of Carriers or Delivery Systems}

It is noteworthy that "naked" RNA, i.e. RNA in the absence of a carrier, is internalized and expressed in dendritic cells (DCs). Already in 1990, Wolff et al. had found naked RNA to be expressed in mice [45], and naked RNA is taken up by many cell types $[43,46]$, although it is in most cell types entrapped in endosomes and degraded in the lysosome, reaching the cytosol only inefficiently $[42,46]$. DCs are an exception, taking up naked RNA with some efficiency [42, 47]. Uptake of naked RNA into DCs was found to involve receptor-mediated endocytosis and macropinocytosis. To allow expression of the RNA-encoded protein, endosomal escape is required, but the exact mechanism of escape is still insufficiently understood [47]. "Naked" DNA has also been reported to be expressed (Wolff et al. in 1990) [45], and a "naked" protein has been reported to be delivered to cells showing activity in the cell nucleus [48, 49].

\subsubsection{Temporal Control of Cargo Efficacy}

The duration of activity for RNA and proteins is transient and limited by dilution due to cell division within days or, in non-dividing cells, by degradation within weeks $[32,50]$. The transient nature of RNA or protein cargoes can be of therapeutic value [42]. If a protein is too long-lived, and if this is not desired for the application, its half-life could be modulated by one of the strategies to influence degradation of a protein of interest [51]. Antibodies that have been delivered as proteins were detectable for up to at least 4 days after delivery [16]. The silencing effect induced by siRNA may last between a few days and more than 3 weeks, depending on how often cells divide and dilute the delivered siRNA [50]. If DNA does not express episomally (extrachromosomally) but integrates into the host genome, the genetic modification can become permanent [32, 52]. For example, a single intramuscular injection of a viral vector that delivered an antibody gene led to lifelong expression of the antibody in mice [53]. Besides the duration of activity, the time until activity starts after administration differs between cargo types. Protein activity can start immediately upon successful delivery to the site of action, without delay. After successful delivery of RNA or DNA, there is a delay until the desired activity takes effect. This delay ranges from a few hours to several days. For example, expression from RNA was detectable already $2 \mathrm{~h}$ after administration [54, 55]; expression of DNA from plasmids or delivered by viral vectors was detectable in the range of 1 to several days post inoculation [55-57]. Expression of mRNA-encoded antibodies peaked at approximately $24 \mathrm{~h}$ after administration and lasted for up to several days or weeks [58-60].

\subsubsection{Comparison of Quantities of Cargo Required for Efficacy}

The dose required for an effect can substantially vary among proteins, from high amounts to only a single protein such as a toxin molecule [61, 62]. For DNA, one to a few transcribed pDNA molecules in the nucleus were claimed to be sufficient for detectable protein expression, due to amplification via transcription and translation [32, 63]. Although gene silencing involves recycling of siRNA, which represents an inherent amplification effect, still more than only a single or a few siRNA molecules are required in the cytosol for successful silencing [32]. Different from the catalytic process of silencing by siRNA, there is no amplification effect for antisense oligonucleotides, but they require equimolar annealing [64]. The expression levels of mRNA-encoded antibodies required for neutralization of targets are expected to be higher than those required for the purpose of vaccination. Naked mRNA was described to be sufficient to induce immune responses, but is potentially not sufficient for applications that require 
Table 1 Comparison of delivery requirements for DNA, RNA and proteins

\begin{tabular}{|c|c|c|c|c|}
\hline & DNA & mRNA & siRNA & Proteins \\
\hline Amplification of effect & $++[32]$ & $+[42]$ & $+[32]$ & - \\
\hline $\begin{array}{l}\text { Predictable association with carrier via ionic interaction } \\
\text { between negatively charged cargo and positively charged } \\
\text { carrier }\end{array}$ & + & + & + & - \\
\hline Functionality with little dependence on tertiary structure & + & + & + & - \\
\hline Integrity of the genome ensured & - & + & + & + \\
\hline Typically transient activity & - & + & + & + \\
\hline Compartment & Nucleus & Cytosol & Cytosol & $\begin{array}{l}\text { Any compartment including cytosol, nucleus, } \\
\text { endosomes, lysosomes, ER, Golgi, mitochon- } \\
\text { dria }\end{array}$ \\
\hline Efficient delivery also to non-dividing cells & - & + & + & + \\
\hline
\end{tabular}

- indicates no, + indicates yes, ++ indicates yes and enhanced relative to "+"

$E R$ endoplasmic reticulum, $m R N A$ messenger RNA, siRNA short interfering RNA

higher amounts of protein and that target other cells than DCs [42].

A comparison of delivery requirements for DNA, RNA and proteins is provided in Table 1.

\subsection{Protein Delivery Applied in Vitro According to Research Areas}

In contrast to in vitro delivery of nucleic acids, which has been an established routine procedure for decades, the delivery of proteins by chemical carriers has remained an exception. Investigating in which research areas protein delivery with chemical carriers has already been applied and which application fields might be particularly promising for this approach may allow valuable conclusions in view of potential future applications. Examples are, therefore, reviewed in Table 2. An example that compared protein delivery of the same cargo with different lipid-based carriers used Fc-Cre as a cargo, a protein consisting of Cre recombinase fused to the constant region of an antibody [16]. Examples of protein delivery by chemical carriers include applications with potential as research-area-independent tools and with potential in the research areas of oncology, neurology, hereditary diseases or metabolic conditions (Table 2). An application of protein delivery that has been pursued by various researchers independently of each other is genome modification (Table 2).

\section{Carriers}

Chemicals used as carriers for biological cargoes typically belong to the group of lipid-based, polymer-based or inorganic nanoparticles [90]. Depending on composition and structural assembly, carriers differ in the mechanism by which they can be loaded with cargo. Premature cargo release is an unwanted effect, but cargo release is often necessary for function $[36,91]$. To avoid the trade-off between requiring complex stability for delivering cargoes into cells and complex instability for release of cargoes at their site of action, stimuli-responsive carriers are an option to initiate cargo release only when desired [92-94].

A carrier ideally fulfils functions in a temporal sequence of tasks, exhibiting specific properties at defined time points [64]. Implementing all functions required for delivery in a time- and location-controlled way as "programmed delivery" $[64,95]$ is a challenge because carriers often need to reconcile opposed properties like being stable outside cells, but dissociating from cargo inside cells, being inert against surfaces, but attaching to the cell surface, and possessing the ability to destabilize membranes of intracellular vesicles but not the plasma membrane or others like the mitochondrial or nuclear membrane [64]. Furthermore, carriers need to fulfil functions that are specific to the cargo type; for example, they need to condense large nucleic acids like DNA [32, $37,38]$.

\subsection{Lipid-Based Carriers}

Lipid-based carriers are typically amphiphiles, containing a non-polar fatty acid chain and a polar head or charged head group. Their amphipathic character allows them to selfassemble in different supramolecular structures like micellar structures, bilayers or vesicles [96, 97]. Lipid nanoparticles commonly employed for nucleic acid delivery are different from liposomes in their structure, for example, assemblies containing micellar structures are referred to as lipid nanoparticles [90]. 


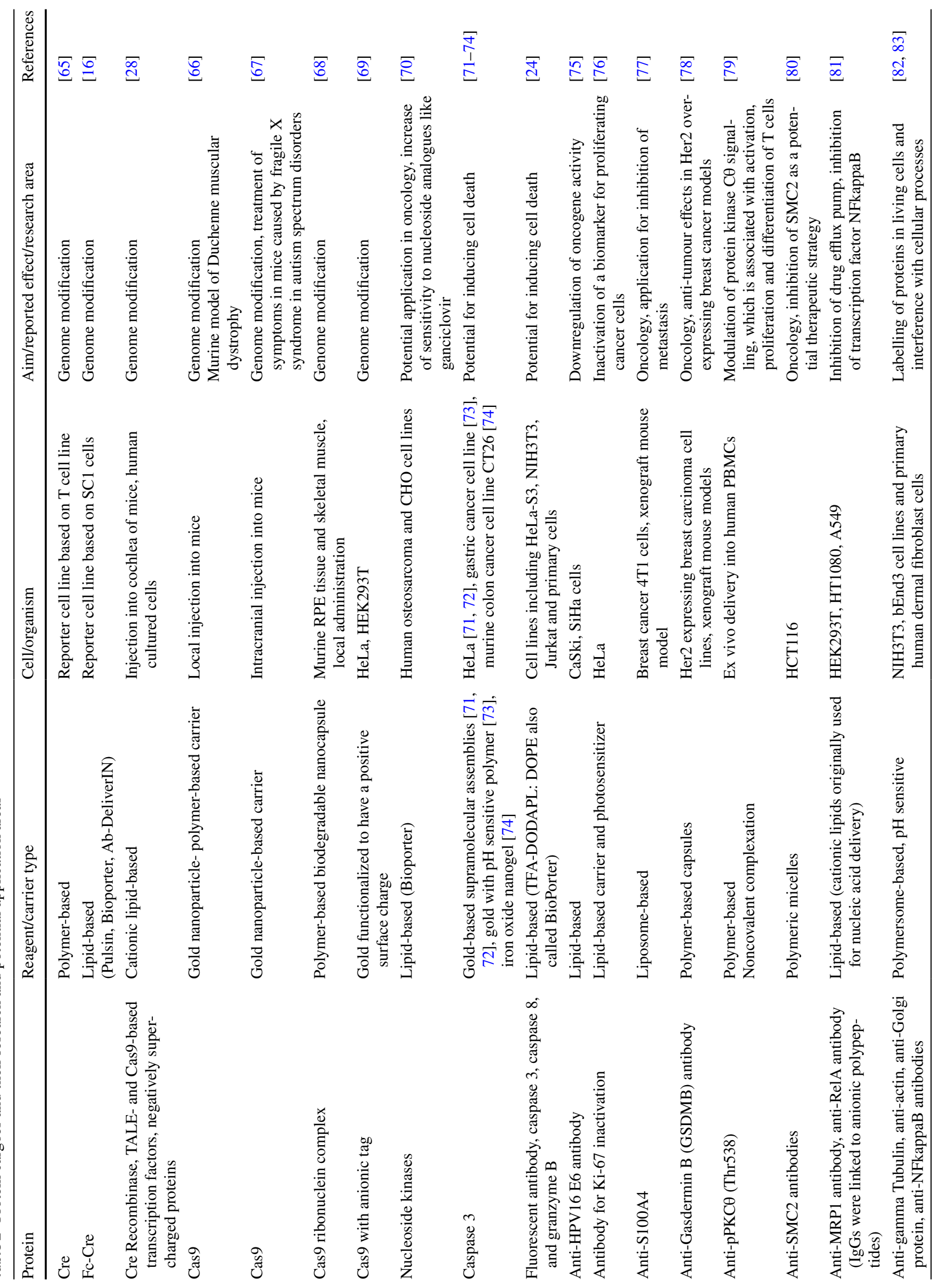




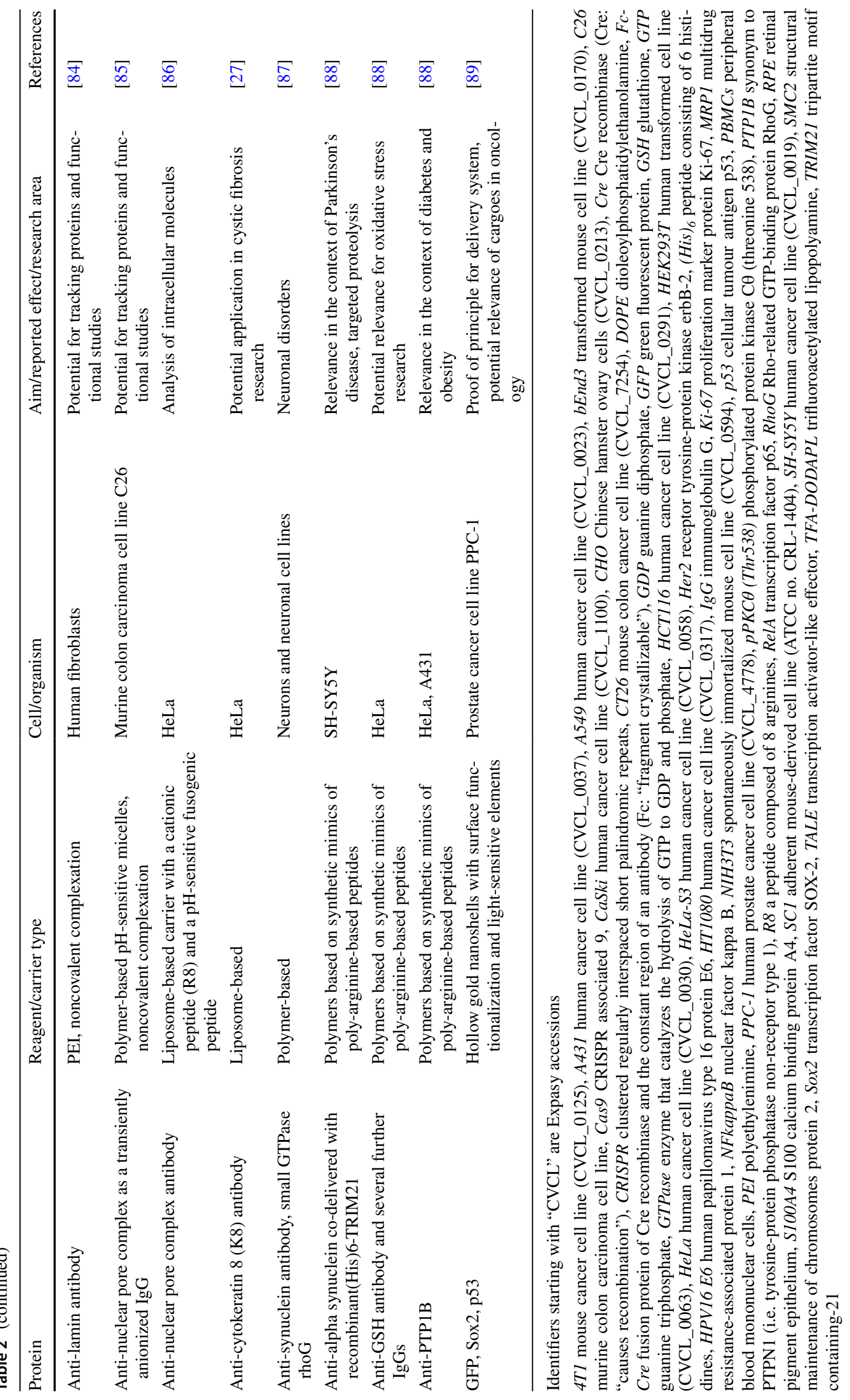


The inner aqueous compartment of liposomes can carry cargoes or the surface of carriers can be loaded with cargoes [24, 25, 96, 97]. Liposomal inner compartments allow carriage of cargoes with various physicochemical properties [98]. Complex formation of carriers with cargoes typically involves ionic interactions [32]. The ratio of surface areas and potentially hydrophobic interactions were relevant for protein cargoes and a cationic lipid-based carrier [25]. Encapsulation of cargoes in liposomes has been described early. Szoka et al. [98] introduced cargoes in an aqueous buffer into a lipid mixture in an organic solvent. The organic solvent was subsequently removed by evaporation, but protein cargoes can be exposed to the organic solvent and denature as a consequence. Still, $41 \%$ of the protein alkaline phosphatase was found to remain active following this cargo-loading procedure [98]. Liposomes can also be prepared without exposing cargoes to organic solvents, for example, by film rehydration [97], by mixing lipid components in an organic solvent and drying the mixture on a solid support like a glass surface, where lipids form a thin layer. When subsequently adding an aqueous solution containing the cargo, vesicles are formed [97].

Typical components of lipid-based carriers are a mixture of four major components: cationic or ionisable lipids, phospholipids, a sterol like cholesterol and a lipid-anchored polyethylene glycol (PEG) [14, 43, 55, 90, 99]. Each component has individual functions, including vial and storage stability provided by lipid-anchored PEG, phospholipids make up the particle structure, cholesterol plays a role in stability and cationic or ionisable lipids promote ionic interactions with negatively charged cargoes as well as cellular uptake and endosomal escape $[90,100]$. New-generation lipids are neutral at physiological $\mathrm{pH}$ and only become cationic at acidic $\mathrm{pH}$, which reduced toxicity and enhanced efficiency $[43,101]$. For example, a lipid formulation that is used as an approved drug for the delivery of an RNA vaccine consisted of ((4-hydroxybutyl)azanediyl)bis(hexane-6,1-diyl)bis(2hexyldecanoate) as an ionisable lipid, 2-[(PEG)-2000]- $N, N$ ditetradecylacetamide as a PEGylated lipid and cholesterol and 1,2-distearoyl-sn-glycero-3-phosphocholine (DSPC) as structural lipids $[14,102]$.

The size of liposomes can be influenced by the choice of the pore size of a membrane through which liposomes can be passed after preparation (extrusion) [97, 103]. The size of lipoplexes depends on various factors, including those that affect complex formation and aggregation [31]. The stability of lipid-based carriers comprises physical and chemical aspects. The physical stability of liposomes includes, for example, their resistance against rupture upon stretching. The chemical stability of lipid-based carriers can be limited by proneness of unsaturated fatty acid chains to oxidation and also by hydrolysis of ester bonds [97].
In summary, lipid-based carriers for cargo delivery can have the advantage of being accessible to many researchers even without requiring chemical synthesis, if mixing of defined reagents in certain optimized ratios is sufficient for preparation of cargo-loaded carriers.

\subsection{Polymer-Based Carriers}

Polymer-based carriers are a very diverse group of carriers in their chemical composition, structure and the mechanism by which they carry cargoes $[64,90,93]$. In contrast to the exactly defined chemical properties of individual components of lipid-based carriers, polymers are often inhomogeneous mixtures with a size distribution. Cargo-loading procedures for polymer-based carriers include cargo association with the surface of carriers, cargo entrapment in the matrix of polymers and encapsulation in or conjugation to the polymer [18, 90].

Copolymers are amphiphilic if composed of a hydrophilic and a hydrophobic polymer block linked together, resulting in similar properties to those of amphiphilic lipids [97]. They can self-assemble and, according to the bilayer-to-vesicle model, assemble to micelles that become bilayer sheets, which eventually close to vesicles (polymersomes) driven by edge energy [94]. The critical packaging parameter $\left[P_{\mathrm{c}}=\nu /(a \times l)\right.$, with $\nu$ as the volume of the hydrophobic part, $a$ as the area of the hydrophilic part and $l$ as the length of the block copolymer] can help estimate which morphology is most likely formed [97]. For example, with a $P_{\mathrm{c}}<1 / 3$, spherical micelles form, with $1 / 2<P_{\mathrm{c}}<1$, vesicles form, and at $P_{\mathrm{c}}=1$, planar bilayers form [97, 104]. Polymersomes tend to be more stable than liposomes, can be stiffer and more resistant against rupture upon stretching than liposomes [97] and often have substantially thicker bilayers $(5-50 \mathrm{~nm})$ compared to the thin bilayers $(3-5 \mathrm{~nm})$ and large inner compartments of liposomes [97]. The risk for disassembly of vesicles upon dilution can be overcome by cross-linking and keeps cargo release independent of dilution [93]. Covalent bonds between polymer blocks are usually more stable than the ester bond in phospholipids. Loading of polymersomes with cargoes is similar to loading liposomes, e.g. by film rehydration [97]. Because there is little control over vesicle size with film rehydration, extrusion, sonication or freeze-thaw cycles are often applied after preparation. Freeze-thaw cycles, especially, are harmful for proteins. A preparation method with better size control is microfluidics based, but has a low throughput compared to film rehydration. Further preparation methods for polymersomes are reviewed elsewhere [94, 97].

In situ cross-linking is used for preparing polymeric nanocontainers, forming around a template that either remains or 
is removed, leaving a hollow shell [93]. Loading may be limited to the particle's surface, because the polymer shell is an obstacle to loading macromolecules into the cavity. A strategy circumventing this obstacle is in situ encapsulation of protein cargoes, which can be achieved by chemically functionalizing the protein with polymerizable groups, letting monomers adsorb to the protein and subsequently polymerizing the monomers as a shell around the protein [18, 68, 93, 105]. In situ encapsulated enzymes may not require release from the polymeric shell if substrates are small molecules that readily diffuse through the polymer meshwork [105]. The polymer shell's purpose can be protection of cargoes from the surrounding environment, like from proteases $[105,106]$. If protein cargoes need to be released from the nanocapsule, degradable polymers can be used $[68,105]$. The stimuli responsiveness of polymers can include stimuli like enzymes, temperature, light, electric stimuli, magnetic stimuli or ultrasound [92-94]. Particularly relevant in the physiological context are $\mathrm{pH}-$, redox- or enzyme-responsive properties, allowing release upon acidification of endosomes or by reduction in the cytosol [68, 92-94, 107].

Nanoparticles from complex hyperbranched polymeric structures (dendrimers) can be covalently or non-covalently linked to biologicals, for example, via charge interactions $[90,108]$. Polycations like polyethylenimine (PEI) or polyamidoamine (PAMAM) can exhibit molecular weightdependent cytotoxicity. To address PEI's weight-dependent trade-off between cytotoxicity and efficacy, stimuli responsive linkers connecting low molecular weight polymers have been suggested and allowed high transfection efficiency at much reduced cytotoxicity $[64,109,110]$.

In summary, polymer-based carriers are highly versatile and highly accessible to rational design when applying the relevant expertise. The assembly mechanism for cargo and carrier has similarities for amphiphilic lipid- and polymerbased carriers. The versatile material properties obtainable with polymeric carriers is an opportunity to strategically engineer parameters affecting delivery efficiency, which are governed by cell-biological and physiological aspects discussed in detail in the section on cells and clinical applications.

\subsection{Inorganic Carriers}

Inorganic carriers comprise materials like gold, silica or carbon nanotubes. Functionalizing the surface of inorganic nanoparticles can be used to promote loading cargoes $[18,105]$. For example, the surface of silica particles was functionalized by covalently linking a hydrophobic surface coating via silanes, which facilitates loading proteins via hydrophobic interactions [111, 112]. A variety of proteins adsorb spontaneously on carbon nanotubes [113]. However, it is important to maintain the protein's function during any type of loading process. Surface functionalization can also promote loading cargoes via electrostatic interactions $[105,114]$. Loading by formation of supramolecular assemblies from gold nanoparticle-based carriers and cargoes has been reported by Rotello et al. [71, 114, 115]. Carriers have been loaded by non-covalent affinity binding via His-tagged proteins on gold nanoparticles functionalized with an anti-His aptamer [116]. Covalent linkage of cargo molecules to carriers is an option if cargoes do not have to be released from carriers or if stimuliresponsive release is possible [117]. Release of cargoes that were covalently linked to the inorganic carrier can be stimuli responsive, for example, gold nanoparticles functionalized via thiol groups released the covalently linked molecules in the reducing cytosolic environment with glutathione [105, 118].

Inorganic nanoparticles are often of interest for applications requiring special material properties, like certain imaging applications [90], but may not require cytosolic delivery. Inorganic carriers that have been used for the purpose of intracellular delivery include mesoporous silica nanoparticles used as carriers for chromobodies. Delivery efficiency was assumed to originate from a proton sponge effect of the $\mathrm{His}_{6}$ tag of the chromobodies, but was very limited in the absence of endosomolytic reagents [119]. Naked gold nanoparticles conjugated with siRNA did not result in silencing and thus did not deliver siRNA to the cytosol [99]. However, inorganic nanoparticles can be functionalized, for example, with polymers to add properties of the polymer. Inorganic nanoparticles that organized into supramolecular structures have been proposed to act via membrane fusion [71, 115]. A non-endocytosis-based entry path that involves membrane disruption has been proposed as a mechanism for delivery of carbon-based carriers, but was associated with toxicity depending on dose and exposure time [20,120].

Eventually, inorganic carriers may allow particular applications that are not possible with organic carriers, but lipid- or polymer-based carriers have so far been used much more commonly for delivering biological macromolecules.

\subsection{Combinations of Chemicals with Other Reagents or Physical Methods}

Combination approaches have been described early, like two components consisting of the polymer poly-L-lysine (PLL) as a carrier to bind and condense DNA for internalization and the small molecule chloroquine to promote endosomal escape $[33,121]$. Bioinspired molecules have been combined with chemicals, for example, a peptide derived from the cell-penetrating peptide TAT has been combined with the small molecule UNC7938 [122]. Further combination 
approaches include peptides combined with lipids [86, 123], liposomes that have been provided with a polymer shell (capsosomes) [97, 124] or lipid/polymer hybrid vehicles, which were combined with a peptide as vehicles for ER targeting [125].

Chemicals have been combined with physical methods like photochemical internalization (PCI) [126-129]. PCI requires a reagent (photosensitizer) that needs to localize in endosomal membranes and forms reactive singlet oxygen, destroying the vesicle membranes upon light exposure [129, 130]. Combination of TAT with PCI was found to result in a certain cytotoxicity, which can be explained by efficient lysis of endosomes accompanied by release of calcium into the cytosol and cell death, but lytic effects were found to also depend on the exact chemical properties of the TAT conjugate [131, 132]. Photochemical disruption of endosomal membranes has been combined with bioinspired reagents like peptides and lipid-based, polymer-based and also inorganic carriers [126-129, 133-136] and has also been used to deliver proteins $[130,137]$. The combination of inorganic glass beads with mechanical "hitting" to deliver photocaged antibodies into cells has also been described [138].

Combination approaches benefit from combined mechanisms acting towards successful delivery. Therefore, they are particularly promising in terms of delivery efficiency, but how well combination approaches can be translated to therapeutic application varies substantially between approaches.

\section{Cells}

\subsection{Mechanisms of Cytosolic Access}

The inherent properties of cells and cellular processes are important to understand when dealing with the delivery of cargoes to their site of action. An example that illustrates the relevance of considering the role of cells in the delivery process is given by von Gersdorff et al., who compared different cell lines and found evidence for cell specificity of the gene delivery process [139]. Particles for nucleic acid delivery typically possess a positive net charge, which allows carrier/cargo complexes to interact with anionic proteoglycans on the cell surface [23, 26]. Much of what is known about delivery with chemical carriers has been observed in the context of DNA delivery, which has a long history [64] of being applied (since the 1960s) [33, 140]. When assessing the cytosolic delivery of proteins, additional aspects need to be considered to ensure methods that avoid artefacts are chosen [16, 26, 141]. Since many carriers for cytosolic delivery of macromolecules are lipid based or polymer based, the following will mostly focus on these carrier types.
The nuclear membrane has to be crossed by some cargoes. Permeabilization of the nuclear membrane by the polymer PEI has been reported as one possible mechanism of nuclear entry, but is associated with toxicity [110]. Although nuclear delivery may occur without cell division $[142,143]$, it occurred to a lesser extent in cells that were non-dividing [144]. Nuclear access is possible upon nuclear breakdown during cell division, which is absent in quiescent and non-dividing cells. If cells were close to mitosis in the cell cycle, transfection was 30- to 500-fold higher with lipid- or polymer-based carriers [144-146]. Nuclear delivery also depends on circumventing degradation by cytosolic enzymes, for example, nucleic acids degrade rapidly within approximately $1-2 \mathrm{~h}$ after injection to the cytosol $[8,35$, 147]. Complexation of DNA to PEI resulted in a tenfold increase in nuclear delivery compared to naked DNA that had been injected into the cytoplasm [142, 147, 148]. Complexation of cargoes with carriers can protect from degradation $[8,35,149]$, but the functionality of cargoes inside cells in most cases also requires release from the carrier $[8$, 150]. For example, expression levels and the time point at which expression from cargo-DNA molecules starts were observed to depend on the release of cargo from the carrier [150-152]. Ideally, DNA remains complexed in the cytosol for protection against nucleases and dissociates from carriers to provide undisturbed access for the transcription machinery to the DNA [148].

An obstacle that needs to be overcome for DNA, RNA and proteins alike is the escape of cargoes from endocytic vesicles [16, 33]. Most carriers are taken up by endocytosis, endosomal entrapment has been described as common $[19,114,153]$, and escape of siRNA is thought to be a rate limiting step for many carriers $[99,154]$. Final readouts like transfection efficiency represent the result of a combined effect of all hurdles, which complicates identifying individual limiting barriers. However, endosomal escape is known as a major limiting factor and crucial determinant for delivering macromolecules to the cytosol $[16,26,33,128,155$, 156]. Even with the use of a lipid-based reagent for endosomal disruption, endosomal entrapment was still marked [19, 27], and the endosomal escape mechanism described by the proton sponge hypothesis is assumed to be generally low in efficiency [115].

Endosomal escape via a targeted disruption of endosomal membranes can be achieved by PCI, but most delivery strategies have to rely on other mechanisms for endosomal escape. Mechanisms for cytosolic entry that have been proposed include fusion with membranes, pore formation, transient disruption or lysis of endosomes [1, 33, 153].

Fusion has been discussed as a potential mechanism to use to enter the cytosol, and in vitro experiments have shown fusion of liposomes [157]. A minor entry path of 
siRNA lipoplexes additional to endocytosis was assumed to potentially be based on fusion with the plasma membrane [158]. Continued delivery of cargo in the presence of various endocytosis inhibitors was suggested to indicate fusion as a major mechanism [159]. A certain structural arrangement has been associated with fusion [160]. Incorporating viral components into liposomes was proposed for generating "fusogenic liposomes" [161-164]. Carriers based on gold nanoparticle supramolecular assemblies have been proposed to act by fusion $[71,115,165]$. However, it can be difficult to determine whether fusion is the primary mode of delivery. Only part of the siRNA cargo of a lipid-based carrier was released from a vesicle to the cytosol [166], which was argued to be inconsistent with fusion, which was expected to result in complete cargo release [153]. Although lipoplexes were assumed to potentially fuse directly with the membrane by some [167-169], others reported the uptake to be energy dependent, and lipoplexes were concluded not to fuse with the plasma membrane, but to be endocytosed $[169,170]$.

Some bacterial peptides that associate with the rim of pores may stabilize open pores by reducing line tension [171]. From experiments with viral peptides, pore formation is known as one of several mechanisms for endosomal escape, but it can be highly size dependent, allowing only molecules of small size to pass. In the case of human rhinovirus serotype 2 (HRV2)-facilitated release of dextran from endosomes, $\sim 27 \%$ of internalized 10-kDa-sized dextran molecules escaped from endosomes compared to only $2 \%$ of internalized $70-\mathrm{kDa}$ dextran molecules [172]. The dimensions of macromolecules were argued by some to be too large for passing through pores potentially formed in the process of delivery by lipid- or polymer-based carriers [153, 156], making it an unlikely escape mechanism for lipoplexes or polyplexes [153]. Pore formation could also be conceived to influence the likelihood for endosomal lysis. Endosomal lysis was discussed as a potential escape mechanism [1]. Pore formation has been proposed to promote endosomal lysis [173], but also to counteract endosomal escape because leakiness of vesicles through pores would reduce osmotic swelling and potential bursting of endosomes [174, 175]. Alternatively, the fusion pore model and the transient pore model both suggest the vesicle remains intact [176].

The proton sponge hypothesis was described in the 90s as a possible explanation for how endosomal escape might occur [33, 108, 177], but has since been under discussion $[1,156,175,178,179]$, because it cannot explain all observations sufficiently. It refers to carriers containing many nitrogen atoms that can be protonated and "soak up" protons like a sponge. Because acidification of endosomes via proton influx has to be balanced by $\mathrm{Cl}^{-}$influx, buffering was expected to lead to unbalanced $\mathrm{Cl}^{-}$ions and thereby cause osmotic pressure and endosome rupture. Protonation of polymeric carriers was additionally expected to result in charge repulsion causing expansion of the polymer network, which may further promote endosome rupture [177]. The proton sponge effect was, for example, assumed to be valid for polymers like PEI [108], PAMAM [180] and poly[2(dimethylamino)ethyl methacrylate) (PDMAEMA) [33, 181].

Evidence arguing for and against the validity of the hallmarks of the proton sponge hypothesis, the buffering effect affecting acidification of endosomes, chloride accumulation and endosomal swelling, carrier expansion and further aspects have been analysed in detail in an excellent review by Vermeulen et al. [175]. Increased buffering capacity of carriers has been associated with increased transfection efficiency in some examples [175, 182-184], while the decrease of PEI's buffering capacity by chemical modification resulted in lowered transfection efficiency. If PEI was not protonated any more in endosomes, gene expression was reduced, consistent with reduced endosomal escape [175, 185, 186]. Evidence that does not seem to agree with the proton sponge hypothesis includes the observation that not all substances with buffering capacity induce endosomal escape and increasing the buffering capacity has not always increased transfection efficiency [175, 187]. For example, a polymer modified with an additional amine group per monomer to provide buffering capacity did not result in the expected effect, but decreased the transfection efficiency. The limiting factor for transfection efficiency was found to be endosomal entrapment of the polymer with the additional amine group, because transfection efficiency was restored by a membrane disruptive reagent. As a conclusion, it was doubted whether the proton sponge hypothesis has general validity considering the aspect of buffering capacity [187]. Also, results with PEI derivatives possessing a decreased buffer capacity but leading to markedly increased transfection efficiencies are not expected according to the proton sponge hypothesis $[175,188]$. Therefore, buffering capacity and transfection efficiency might not always be correlated [33, 187, 189], so additional aspects may determine the final transfection efficiency and endosomal escape. Acidification towards pH 5 occurs quickly in endocytic vesicles, within only a few minutes [190]. Intracellular pH measurements seem to not always confirm the proton sponge hypothesis $[178,191]$. Although polyplexes did not change the lysosomal $\mathrm{pH}$ and Benjaminsen et al., therefore, concluded the proton sponge effect not to be the dominant escape mechanism [178], acidification can be delayed even if the luminal $\mathrm{pH}$ of endosomes is not changed [33]. Consequently, buffering effects may not necessarily increase $\mathrm{pH}$ as a final result, but slowed down acidification of endosomes in the presence of buffering polymers was reported, consistent with the proton sponge hypothesis [175, 178, 182]. Evidence has been provided for proton influx being accompanied by chloride ion influx, and vesicles have been observed to 
increase in size with PEI [182]. Although this is consistent with unbalanced chloride ions causing osmotic swelling of vesicles, it has been questioned whether vesicles are likely to reach the osmotic pressure required for rupture [175, 192]. If not entirely responsible for making endosomes rupture, osmotic pressure could still be imagined to aid in disrupting membranes [175, 192]. The size of endosomes is celltype dependent, and smaller vesicles rupture more easily unless potential vesicle leakiness does not exceed a certain threshold, above which it will not rupture independently of its size $[174,175]$. Even only a few bursts of vesicles might be sufficient for transfection, if they occur $[175,179]$. While burst-like release from endosomes associated with polymerbased carriers was reported by some [179, 193], no bursting of endosomes was observed by others for a lipid-based carrier [99]. Even burst-like release of cargoes from endosomes delivered by polymer-based carriers did not lead to complete lysis of endosomes, but endosomes remained intact after a sudden local release event [179]. For a lipid-based carrier, cargo release was not altered by a proton pump inhibitor [99], and results were consistent with a mechanism based on lipid exchange [99, 194]. Expansion of carriers has been proposed to assist endosomal escape by causing mechanical pressure [156, 195]. According to the "umbrella hypothesis", electrostatic repulsion of groups that become charged upon protonation in a polymer causes the polymer to expand from a collapsed to an extended conformation, which might aid endosomal escape. An increase of volume by swelling of the polymer has indeed resulted in higher transfection efficiency, for example, fractured PAMAM dendrimers having an increased volume change upon protonation caused higher transfection efficiency compared to intact dendrimers [196, 197]. A pH-responsive polymer increased its diameter from $\sim 200$ to $\sim 550 \mathrm{~nm}$ [198]. Transfection efficiency was higher for nanoparticles with higher swelling [199]. Carrier expansion might be a contributory factor to endosomal escape among further mechanisms [175, 191, 198].

\subsection{Updated Model for the Mechanism of Endosomal Escape and Further Hypotheses}

Successful escape from vesicles most likely occurs after multiple mechanisms have acted together [200]. Revised proton sponge hypothesis versions and further endosomal release theories have emerged and been discussed [33, 153]. Schubert et al. discusses the models of "polyplex hole formation" and "free polymer hole formation" [33]. These models differ from the proton sponge hypothesis in taking charge-driven interaction of carriers with the membrane into account, which might complement the proton sponge hypothesis in explaining endosomal escape, as also suggested by Vermeulen et al. [33, 175].
Buffering, swelling of vesicles, carrier expansion upon $\mathrm{pH}$ change, local membrane destabilization and potentially further aspects might influence endosomal release separately or combined, and the escape mechanism has to be considered individually for each carrier [33, 175, 200]. Based on the discussion by Vermeulen et al., an endosomal escape mechanism can potentially be imagined as follows: a polymeric carrier buffers protons, leading to both osmotic pressure causing swelling of endosomes and to charge repulsion causing expansion of the polymer. A local perturbance of the membrane may eventually trigger disruption of the already swollen and potentially mechanically, by expanded polymers, strained endosomal membrane [175]. According to Rehman et al., the release of endosomal contents originates from a particular region, which might point to the local disturbance [179]. However, if membrane destabilization does not lead to "pinching" of a vesicle that is close to bursting, it might instead lead to leakiness of the vesicle, which may counteract the build-up of osmotic pressure and render endosomal escape inefficient compared to bursting endosomes $[174,175]$.

Interaction of carriers with membranes may, therefore, be an important factor for endosomal escape. Simulations, studies with supported lipid bilayers (SLBs), in vitro experiments with the patch clamp method and atomic force microscopy have been used to analyse the effect of polymers on membranes [201-204]. Artificial lipid bilayers and cell membranes are damaged by polycationic organic nanoparticles, for example, membranes are damaged by PEI, PAMAM or PLL [201-203, 205-207]. Cationic polymers were found to cause membrane hole formation and thinning and disruption of membranes [201, 202, 205]. For example, PEI was found to interact with and disrupt lysosomal membranes by electron microscopy [208]. Studies with SLBs revealed thinning of membranes or hole formation induced by cationic polymers [201], and membrane defects were detected in living cells using patch clamp [203]. There is evidence that free PEI polymers, i.e. polymers that are not complexed with cargo, can play an important role in destabilizing membranes. Non-complexed PEI contributes to high transfection efficiencies, but also to toxicity [209, 210]. Free polymer was suggested to interact with membranes in a "carpet structure", causing defects or intercalating into the plasma membrane even before endocytosis [33, 210]. Lipid-based carriers were suggested to engage in destabilization of endosomal membranes [211] and were reported to cause perturbance of endosomal membranes by promoting the transition from bilayers to nonbilayer lipid structures [194]. An event that was suggested to initiate the process described as the "fusion pore model" is the occurrence of anionic lipids in the inner leaflet of the endosomal membrane, which have by "flip-flop" turned from the outer cytosolic to the inner 
luminal leaflet of the endosomal membrane, promoting lipid mixture and cargo translocation [176]. The "flip-flop" mechanism was proposed to be induced by the carrier/cargo complex and assumed to have initiated endosomal escape of oligonucleotides delivered by a cationic lipid-based carrier [212]. Cationic lipid-based carriers may interact with anionic lipids that have, upon destabilization, rearranged by flip-flop to the inner monolayer of endosomal vesicles and promote lipid mixing and endosomal escape [176, 211]. The biomimetic reagent TAT, which is also cationic, has been found to induce lipid mixing in endosomes [213, 214].

Nanoscale hole formation or local destabilization of the membrane while the whole endosome remains intact was proposed as a possible consequence of polymer interaction with membranes and is assumed to be a charge-driven local destabilization leading to transient nanoholes [33, 179, 201]. This is consistent with rupture of entire vesicles being unlikely or rare and with the observation of cargo release by transient local bursts instead of complete vesicle lysis by live imaging $[33,99,179]$.

Vesicle budding and collapse is a model proposed to explain macromolecular escape consistent with escape under maintained endosomal integrity [153]. It has been questioned whether the size of holes formed in the presence of carriers would be sufficient to let cargoes or their complexes with carriers pass [33, 153,215]. According to this model, membrane curvature is induced in the membrane, followed by budding off of a small entity, which is assumed to subsequently disintegrate in the cytosol, releasing its contents while leaving the endosome behind intact [153]. The model of vesicle budding and collapse was described for cell-penetrating peptides [153,216], but not for other carriers. Authors argue it might potentially apply to further carriers and explain escape even if membrane holes are too small for letting macromolecules pass.

Some carrier types may induce endosomal escape upon disassembly, which has been proposed to cause an osmotic shock due to the increased particle number, leading to vesicle rupture [156, 217]. The mechanism of escape for a type of hydrolysable polymersomes was furthermore suggested to involve action as a detergent upon degradation, thereby, destabilizing the endolysosome $[200,218]$.

Apart from the mainly carrier-focused models for endosomal escape mentioned before, less carrier-focused mechanisms have been proposed. Leakiness of vesicles has been suggested as a possible mechanism contributing to endosomal escape, has been attributed to macropinosomes including macropinosomal lysis $[99,219]$ and is cell-type dependent [174]. Also, naked RNA has been reported to be delivered, i.e. delivery of RNA without any carrier-induced silencing $[45,220]$, although the mechanism by which it escapes macropinosomes and reaches the cytosol is still incompletely understood $[42,47]$.
If the mechanism of endosomal escape is qualitatively correctly described, it might eventually be the efficiency with which this mechanism acts that governs the number of molecules able to reach the cytosol or nucleus.

\subsection{Efficiency}

High apparent endosomal escape efficiency has been attributed to some reagents like dimeric fluorescent TAT (dfTAT), although the percentage of molecules that entered cells was acknowledged to be small compared to the extracellularly administered amount [148]. PCI-mediated delivery has been reported to allow efficient endosomal escape $[129,130]$.

Detectability of endosomal escape by conventional fluorescence microscopy is unusual, because dilution of cargoes from burst endosomes in the cytosol often renders them undetectable [99]. Gilleron et al. used electron microscopy to detect escaped cargo, because only a few hundred cargo molecules might escape from endosomal compartments and release from bursts of vesicles was rare, as indicated by the stable numbers and contents of vesicles over time. Therefore, escaped cargo might not be detectable by standard fluorescence microscopy [99]. Often, endosomal escape is detected by indicators that are sensitive to even small amounts of escaped cargo. For example, gene knockdown was reported to require only 2000 cytosolic siRNAs or fewer [166]. A number of 500 siRNAs per cell allowed a 50\% target reduction in vivo in rats [221], and an estimated number of 370 siRNA copies per mouse liver cell was required for a $50 \%$ knockdown, being within a similar range [222]. For DNA as a cargo molecule, a number of 75-3000 copies of plasmids in the nucleus was sufficient to induce measurable transgene expression [36]. Further readouts employed as indicators of endosomal escape include toxicity or enzymatic activity, like that of beta-lactamase or Cre recombinase. Toxicity as an indicator for endosomal escape can be highly sensitive, because single toxin molecules can be sufficient to kill a cell [61, 62, 223]. For beta-lactamase activity, 50 molecules in a single cell have been sufficient for detection [224]. For Cre recombinase, four Cre molecules are theoretically sufficient for recombination [148]. Therefore, proof of endosomal escape does not always originate from escape of large amounts of cargoes if detection methods are highly sensitive.

Only approximately $1-2 \%$ of siRNA applied with a lipidbased carrier was reported to escape into the cytosol from endosomes [99]. A similar range with about $3.5 \%$ of internalized siRNAs reaching the cytosol was reported for siRNA associated with a lipid-based carrier by another study [166]. Naked RNA was reported to be capable of entering the cytosol as well, but fewer than one in 10,000 molecules typically reach the cytosol [42].

For plasmids delivered by lipid-based or polymer-based carriers, only $1-5 \%$ of the total applied doses were reported 
to reach the nuclear fraction, corresponding to between 75 and 50,000 plasmids per nucleus, depending on the applied DNA dose [36]. Only $10-20 \%$ of the total dose was detected in total cell lysates after application of lipidbased or polymer-based carriers [36]. Glover et al. analysed the endosomal escape efficiency and nuclear delivery of a polymer-based and a lipid-based carrier by real time polymerase chain reaction (PCR) and flow cytometric detection of protein expression. Depending on the carrier, per cell, $0.8 \%$ and $0.4 \%$ of the total amount of DNA cargo administered reached the nucleus. Approximately 350 plasmids $/ \mathrm{h}$ were delivered within the first $8 \mathrm{~h}$ of exposure, and after $24 \mathrm{~h}$ of exposure, LipofectAMINE2000 (LF2K) resulted in the delivery of $8.3 \times 10^{3}$ plasmids and PEI in the delivery of $1.8 \times 10^{4}$ plasmids to the nucleus from a total of 4 $\mu \mathrm{g}$ of plasmid $\left(2.2 \times 10^{6}\right.$ plasmids per cell $)$ to which cells were exposed [225]. According to Gilleron et al., approximately 200 siRNA-gold particles escaped endosomes per cell during a 6-h time period in HeLa in vitro or hepatocytes in vivo, which corresponds to a maximum of 2000-4000 siRNA molecules per cell [99]. In HeLa cells, endosomal escape occurred in only $10 \%$ of the endosomes containing polyplexes, although endosomes were small and, therefore, even pose favourable conditions for escape [174].

Biomimetic approaches are not the focus of this review, but for comparison the TAT peptide and Antennapedia peptide (pAntp) were reported to result in an endosomal escape efficiency of $\sim 2 \%[148,226,227]$. The pAntp was reported to result in $\sim 2 \%$ of internalized peptides reaching the cytosol, which was only $0.015 \%$ of the total amount applied, resulting from an experiment in which $10^{6}$ cells were incubated for $2 \mathrm{~h}$ with $1 \mu \mathrm{M}$ pAntp (corresponding to $\sim 1.2 \times 10^{8}$ molecules/cell; $9 \times 10^{5}$ molecules/cell pAntp were internalized and $1.8 \times 10^{4}$ molecules/cell reached the cytosol) $[148,227]$.

DNA delivery was found by Rehman et al. to originate from only one to two polyplexes per cell on average [179]. Complexation to a carrier can protect cargoes until the nuclear barrier has been overcome, as the comparison of microinjected free and complexed DNA has demonstrated. While less than $0.1 \%$ of naked DNA reached the nucleus after microinjection, $1 \%$ of DNA in a polyplex reached the nucleus after microinjection [142]. The same plasmid number in the nucleus may not always result in the same expression levels, but also depends on how accessible plasmids are for the cellular expression machinery, for example, a similar number of plasmids per nucleus resulted in a ten- to 100-fold higher luciferase expression if plasmids had been delivered by lipofectamine compared to those that had been delivered by PEI [36]. The efficacy of the cargo at its site of action may further be related to its individual mode of action. Knockdown has been observed to be nonproportional: only 370 copies of siRNA mediated a $50 \%$ knockdown, but to reach an $80 \%$ knockdown, 2200 copies of siRNA were required [197, 222]. Protein expression from DNA may reach saturation, even if the number of plasmids/ nucleus continues to rise. For example, with a 3.5- and 17.8-fold increase in plasmids/nucleus, protein expression increased only 1.3- and 1.4-fold in a mouse melanoma cell line [36]. With $90 \%$ of CRISPR Cas9 (clustered regularly interspaced short palindromic repeats associated protein 9) co-delivered with guide RNA to HeLa cells, a gene editing efficiency of up to $30 \%$ was reached [69]. The speed of delivery has been observed to be rapid, with endosomal escape occurring within 5-15 min of endocytosis or as reported by Wittrup et al. [166].

In vivo, the most easily accessible tissue is liver tissue, but efficiency is low even in liver tissue, with only $0.1 \%$ of total siRNA delivered, while the remaining fraction is degraded or does not reach the cytosol [197, 222]. In vivo delivery by local injection into the cochlea of mice resulted in Cas9:single guide RNA (sgRNA) complex-mediated genome modification in $13-20 \%$ of outer hair cells near the injection site [28].

\subsection{Endocytosis/Intracellular Trafficking and Its Relevance to Escape}

The question might arise as to whether the barrier that carriers have to overcome for escaping endosomes is independent of the endocytic pathway, or whether the uptake route may influence delivery efficiency. Phagocytosis mainly allows special cell types (phagocytes) to internalize large particles like pathogens and target them to the lysosome for degradation. Pinocytosis includes the endocytosis subtypes clathrin-mediated endocytosis (CME), caveolae-mediated endocytosis (CvME), clathrin- and caveolae-independent endocytosis or macropinocytosis [228, 229] and serves functions like nutrient uptake or cellular signalling [229, 230]. Macropinocytosis allows uptake of larger volumes of extracellular fluid, and the formation of membrane ruffles preceding macropinocytosis can be triggered by growth factors, viruses or bacteria [231].

Although the mechanism by which intracellular trafficking might affect delivery efficiency is not fully understood, there is evidence for an influence of the uptake route on final delivery efficiency [232-235]. Transfection with PEI was most efficient when uptake took place via CvME [234], which was not associated with lysosomal localization of polyplexes [233, 235]. Clathrin-mediated uptake resulted in lower transfection efficiency and lysosomal degradation [233]. Contrary to these findings, in a study with lipid- and polymer-based carriers, high transfection efficiency was found to be associated with CME, but not caveolae-mediated uptake and the endocytic route taken was more decisive than the amount of internalized 
particles [236]. A difference in internalization efficiency and cytosolic delivery efficiency was also observed in an example of transferrin-receptor-mediated uptake of polyplexes. More than $95 \%$ of cells had taken up transferrin polyplexes, but cytosolic delivery was moderate, requiring chloroquine for enhancement [237]. CME followed by macropinocytosis was a delivery route for siRNA and a lipid-based carrier, with a major contribution of macropinocytosis to gene silencing [99]. A comparison of uptake into four different cell lines showed internalization to occur through multiple endocytic pathways, but mostly only one endocytic pathway resulted in cargo delivery. Which pathway was productive was cell-type dependent [169]. Besides depending on the carrier, uptake routes are generally highly cell-type dependent [33, 238]. In HEK293 cells, RNA interference (RNAi) was facilitated via Graf1mediated endocytosis (GME) [169], a pathway via which also dextran is internalized [239]. Arf6-dependent endocytosis (ADE) initiated RNAi in HeLa and HepG2 cells [169]. Blocking "non-productive pathways", i.e. pathways that did not contribute to cytosolic delivery, could be a strategy to improve delivery efficiency by shifting cargo uptake to "productive pathways", as demonstrated by Vocelle et al. [169].

Autophagy was reported to lower delivery efficiency [240] and can be triggered by carriers [240, 241] by carrier-induced damage of endosomal membranes [166, 241]. Autophagy is considered to be a barrier to delivery by some $[1,240]$, but others argue it may have no influence on delivery efficiency, with endosomal escape occurring earlier than autophagy $[1,166]$.

Recycling may affect gene delivery efficiency [242, 243]. Recycling was reported to limit the cytosolic delivery of siRNA, and up to $70 \%$ of internalized siRNA lipid complexes were exocytosed. Lack of a regulator of recycling pathways increased retention of carriers in the cells and increased gene silencing [242].

Intracellular trafficking and how deeply cargoes are transported into the cell is relevant for DNA delivery [197]. PEI/ DNA complexes were transported within minutes along microtubules to the perinuclear region [244]. Uptake of cargoes exclusively at the periphery, e.g. by fusion with the plasma membrane, would be disadvantageous for nuclear delivery because large complexes typically sized $80-500 \mathrm{~nm}$ diffuse slowly through the cytoplasm without active transport $[197,245]$. Further, it is preferable if destabilization of membranes occurs in the endolysosomal system, because plasma membrane destabilization affects cell viability [191]. Exposure to the cytoplasmic environment for prolonged time periods increases the risk for cargo degradation [147].

The size of endosomal vesicles may influence escape efficiency, because it is relevant for a vesicle's propensity to rupture [174]. The internalization route can be influenced by particle size [39, 246]. DCs efficiently internalize particles sized below $500 \mathrm{~nm}$, which comprises the typical size range of viruses ( 20-450 nm) [247, 248]. Macropinocytosis allows uptake of large particles, macropinosomes having a size range of approximately $>0.2-5 \mu \mathrm{m}$ [249-251]. CME can be an uptake route for particles with sizes of $\sim 200 \mathrm{~nm}$ or less. Clathrin-independent endocytosis was suggested to internalize particles larger than $200 \mathrm{~nm}$ and up to at least 500 $\mathrm{nm}$ in size. This might be relevant for delivery efficiency, because 200-nm-sized particles, but not 500-nm-sized particles, trafficked to late endosomes and lysosomes in the murine melanoma cell line B16 [39]. However, it is cell-type and carrier-type dependent which endocytic pathway is productive in contributing to cytosolic cargo delivery [139]. For example, CME was a productive pathway for a lipid-based carrier in HeLa cells or for a polymer-based carrier in Cos-7 cells. For other cell line and carrier combinations, clathrinindependent endocytosis was the major productive uptake route, or more than one pathway was productive [139, 233]. Liposomes and polymersomes typically have sizes within a broad range of several tens of nanometres to up to more than $10 \mu \mathrm{m}[94,97]$. Lipid- or polymer-based nanoparticles are typically in the range of several tens to several hundreds of nanometres [1]. Polymer nanocontainers are typically sized 10-500 $\mathrm{nm}$ [93]. Inorganic carriers vary much in size, depending on the individual carrier type, ranging from below $10 \mathrm{~nm}$ to several micrometres [1]. Besides their individual particle diameter, inorganic nanoparticles can form larger superstructures assembled from smaller particles [71, 115]. The most efficient delivery was observed for particles sized 130-215 nm in a study with different carriers and a myoblast cell line [236]. A size range of 10-60 $\mathrm{nm}$ has been suggested to be most suitable for internalization of most nanoparticles into non-phagocytic cells. Although smaller nanoparticles were found to internalize better, those that are below $30 \mathrm{~nm}$ were also reported to be insufficient activators of endocytosis, narrowing optimal size ranges further [252].

Possible unwanted fates of internalized material include trafficking to recycling endosomes followed by exocytosis or trafficking to lysosomes or uptake into autophagosomes followed by transfer to lysosomes before endosomal escape occurs [33]. Impaired integrity of lysosomes may cause cell death $[253,254]$, rupture of lysosomes can trigger apoptosis $[156,255,256]$ and, therefore, might not be a suitable escape mechanism. There is a limited window of opportunity within which escape may occur, an optimal time point for escape likely being between early endosomes and fusion with lysosomes [33, 156]. Results from experiments with siRNAs and lipid-based carriers were consistent with escape from early endocytic structures that are hybrid compartments sharing characteristics of early and late endosomes [99]. In experiments with Niemann-Pick C1 protein (NPC1)deficient cells, accumulation in enlarged late endosomes 
was associated with greater gene silencing efficiency, suggesting late endosomes as sites of escape for lipid-delivered siRNA [242]. Late endosomes were also the preferential site of escape for oligonucleotides applied in the presence of small molecule compounds for enhancing endosomal release [257]. Endosomal release was observed in a narrow time window of only $\sim 10$ min for siRNA with a lipid-based carrier [166]. The window of opportunity for escape may broaden if trafficking is delayed. The formation of early/late endosome hybrid compartments with delayed trafficking to lysosomes could be imagined to allow cargoes to spend more time in a compartment from which escape may occur [99, 242, 258]. Impeding intracellular trafficking to lysosomal compartments was proposed to re-route cargoes into a novel compartment and increase the chance of cargo escape from vesicles [176, 259]. Also, the amount internalized in cells that is not exocytosed, i.e. the general retention of cargo in cells, may influence escape efficiency [242, 243]. The window of opportunity for cytosolic entry might, therefore, be broadened by escape from recycling pathways and influenced by the amount of cargo and residence time within the cell. Nevertheless, the efficiency of endosomal escape can still vary substantially, even if all treated cells have internalized carriers and cargoes [236, 260]. Analysing internalization routes of materials into cells requires a certain scrutiny when interpreting data, because small molecule inhibitors commonly used for endocytic pathways often lack specificity [261]. Furthermore, continued uptake of a substance under inhibition of a pathway is not always informative, because the pathway is either not involved in uptake or it is involved but not detected, because the blocked pathway is compensated for by activation of another pathway [262]. Eventually, endocytic pathways themselves may have been misinterpreted in the past, caveolin-positive vesicles potentially carrying ubiquitinylated caveolin targeted for degradation instead of representing a compartment type [263].

\section{Preclinical and Clinical Applicability}

\subsection{Extracellular Barriers}

In addition to intracellular barriers, extracellular barriers need to be overcome for therapeutic application (barriers summarized in Fig. 1). Only seven of 1000 delivered carriers entered a tumour in mouse models according to a comparative literature analysis spanning a time period of 10 years until 2016 [264]. Some extracellular barriers apply generally, and some are specifically relevant to cytosolic delivery of macromolecules. General factors include biodistribution, access to target tissues or target cells, in vivo stability and circulation half-lives of the drug. Specific barriers for in vivo cytosolic macromolecule delivery may be caused by in vivo effects affecting intracellular trafficking or endosomal escape. Toxicity beyond the cellular level may also occur, for example, PEG may exhibit renal toxicity at high doses [265].

The administration route influences the distribution of particles; for example, after intravenous administration, a polymer has been observed to mainly target the liver and spleen, while subcutaneous or intranodal administration resulted in accumulation in local lymph nodes [90, 266]. Particle distribution across organs is size dependent [267, 268], and small particles with diameters of $6 \mathrm{~nm}$ are rapidly cleared by the kidneys [64, 269].

Depending on administration route and target organs, physical barriers like mucus layers in the lung can be relevant, or the blood-brain barrier, as an obstacle to delivery to the brain [90]. Leaving the bloodstream and accessing target tissues requires overcoming endothelial layers, which have different permeability (gaps in the range of $1 \mathrm{~nm}$ to over $100 \mathrm{~nm}$ depending on tissue) [8]. A special case is tumour vasculature, which is leaky and, therefore, potentially advantageous for drug delivery. The "enhanced permeation and retention effect" (EPR effect) has been proposed as a mechanism to explain preferential accumulation of drugs in tumours [8, 270]. However, the impact of the EPR effect is not entirely clear and may be limited if only $0.7 \%$ of injected nanoparticles reach the tumour site [90, 264, 271]. An interaction of only $2 \%$ of tumour cells with nanoparticles was reported in one case [271]. In tumour microenvironments, special conditions prevail, posing additional barriers, including limited perfusion of nanoparticles into the tumour, dense extracellular matrices and degradative enzymes [90, 271-273]. Overproduction of extracellular matrix (ECM) as a dense mesh may pose a physical barrier to nanoparticle delivery [90, 264, 271], which is particularly true for cationic nanoparticles that interact with the negatively charged ECM [90].

Discrimination between target cells and non-target cells can be required for therapy. If cargo delivery is nonspecific, promoters could be used for nucleic acid cargoes that allow tissue-specific cargo activity. Targeted delivery using receptor-specific antibodies can be another strategy. Targeted delivery has been attempted including brain, liver, lung or tumour tissue targeting [64].

\subsection{Extracellular Barrier: In Vivo Stability}

Stability issues related to in vivo conditions may include chemical and colloidal stability. Cargoes can be exposed to enzymes like, for example, RNAses in the extracellular space [274]. The in vivo environment can affect stability by affecting the nanoparticle's aggregation propensity [275]. High ionic strength in biological fluids may affect the tendency of nanoparticles to aggregate [275, 276]. For 


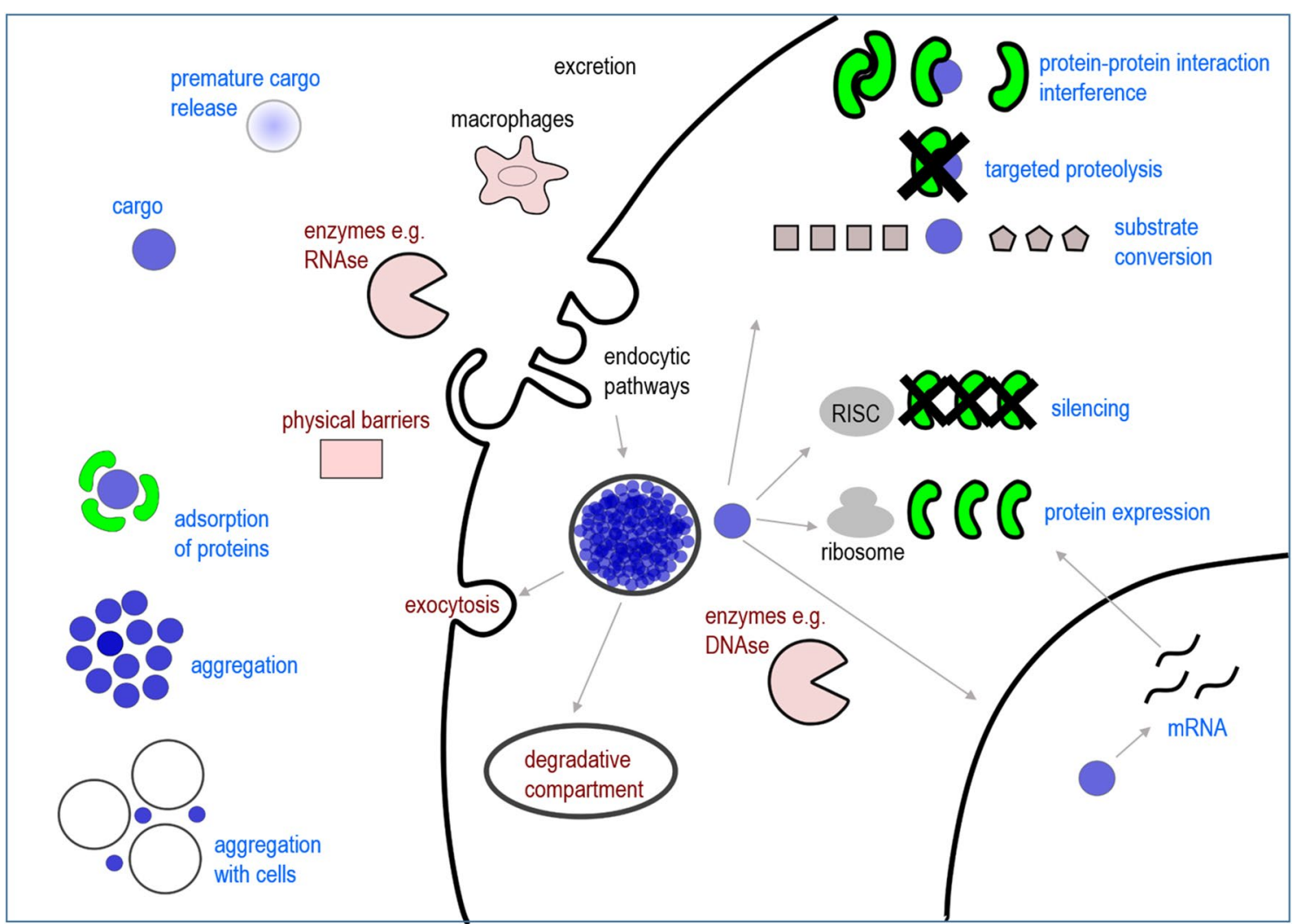

Fig. 1 Summary of intracellular and extracellular barriers. Chemicals as carriers for the delivery of macromolecules like DNA, RNA or proteins typically associate with their cargo and are internalized by the cell via one or several endocytic pathways. Intracellular barriers to delivery include endosomal entrapment, exocytosis or elimination in a degradative compartment before endosomal escape, the presence of degrading enzymes and insufficient release of the cargo from its carrier at its site of action. Extracellular barriers for cargo delivery include premature cargo release from the carrier and adsorption of proteins from biological fluids like serum proteins, which may for

example, DNA/PEI complexes aggregated at physiological ion concentrations to large particles of up to approximately a micrometre in size $[275,276]$. Carriers may also form aggregates with cells in the blood stream [277]. Aggregate size may influence the endocytic uptake route taken [278], and if aggregate sizes are large enough, they embolize capillaries [8, 279]. Shear forces and the adherence of serum proteins like albumin contributed to the dissociation of polymer micelles as observed from in vitro experiments and in blood vessels of mice $[262,280]$.

Non-specific adsorption of biomolecules on nanoparticles from the environment can form a "corona" on the particle surface in vivo [90, 156, 275, 281, 282], and its composition depends on particle-size and particle-surface properties [283] as well as tissue-specific presence, adsorption or desorption of proteins in the environment of the particle [90, 284]. The corona can influence tissue distribution, cellular delivery efficiency and circulation times of the drug [90, instance affect tissue distribution. Extracellular barriers may be posed by changed aggregation behaviour of carrier/cargo complexes in the extracellular space (e.g. aggregation of complexes to larger particles or formation of aggregates with cells in the blood), which can influence intracellular delivery and may even pose a risk for blocking capillaries. Extracellular barriers further include excretion mechanisms, elimination by the immune system or degradation of cargoes by extracellular enzymes and physical barriers. DNAse deoxyribonuclease, $m R N A$ messenger RNA, RISC RNA-induced silencing complex, RNAse ribonuclease

285, 286]. As an example, if apolipoprotein E (ApoE) is adsorbed to carriers or if components of the carriers mimic ApoE, this influences the distribution of carriers by targeting to low-density lipoprotein (LDL) receptors and subsequent delivery to hepatocytes [90, 286, 287]. Plasma proteins that have been reported to interact with lipid-based carriers and to influence their in vivo performance include highly abundant proteins like albumin, which may cause destabilization of particles or proteins that promote clearance by the immune system like complement proteins or immunoglobulins [288]. The immune system may contribute to rapid clearance via phagocytes if molecules in the corona act as opsonins [289, 290]. In an analysis of lipid-based carriers, it was observed that if carriers disintegrated in the presence of serum proteins with cargo release, in vivo transfection efficiency was poor, but carriers that aggregated and only slowly disintegrated upon exposure to serum proteins were efficient at transfecting cells [291]. 
Shielding agents like PEG have been used for carriers to prevent aggregation and to prolong blood circulation time [90, 277]. However, PEG may also induce anti-PEG antibodies and result in accelerated blood clearance [292].

Carriers are more rapidly cleared in vivo if they are cationic and have the longest half-lives if they are neutral [268, 293].

Circulation half-lives are influenced by excretion and clearance by the immune system. The optimal size of nanoparticles should be above $10 \mathrm{~nm}$ for preventing excretion via the kidneys, but has been suggested to ideally be not larger than $200 \mathrm{~nm}$, a size that fits well through microcapillaries [156, 294].

\subsection{Extracellular Barriers for Macromolecule Delivery to the Cytosol in Particular}

Intracellular barriers that are specific to the in vivo environment add to the general intracellular barriers. The "biological identity" of particles that forms through adsorption of biomolecules in the in vivo environment may influence delivery if affecting endocytosis. Indeed, the corona of biomolecules on particles was reported to affect the quantity and also the mechanism of uptake. For example, protein coronas can decrease the uptake of particles and also may influence by which endocytic pathway they are mainly taken up [295-297]. A mechanism by which the endocytic pathway taken can be affected by biomolecule coronas is the promotion of receptor-mediated endocytosis via a biomolecule that is enriched in the corona and can act as a ligand for a specific receptor [297].

The formation of protein coronas can be counteracted by PEGylation, which is also beneficial in prolonging circulation half-lives, but PEGylation has been found to inhibit endosomal escape [176, 298, 299]. Another example for a strategy to enhance in vivo utility that impairs cytosolic delivery is cross-linking the surface of a polyplex to increase "lateral" stability, which increased circulation half-life, but resulted in a decreased intracellular cargo delivery as indicated by decreased transgene expression $[8,300]$.

\subsection{Examples of Clinical Potential and Clinical Applications}

The long list of approved nanoparticles, polymer based, lipid based or inorganic, demonstrates the safety and clinical utility of chemical carriers [90, 301], although mostly not applied for cytosolic delivery of macromolecules. Magnetic, radioactive or optical properties make inorganic nanoparticles suitable for diagnostics or particular therapies like photothermal therapies [90]. An approved inorganic nanoparticle is NBTXR3 (Hensify ${ }^{\circledR}$, Nanobiotix, Paris, France, EU), 50-nm particles from hafnium oxide, which act without delivering cargoes by physically enhancing radiotherapy [302, 303]. Liposomal drugs carrying small molecule chemotherapeutics as cargoes have been approved by the Food and Drug Administration (FDA) [90, 302], and nanoparticles are used for controlled release of small molecule drugs, protecting from rapid clearance in the body and allowing drug action with prolonged duration. Delivery of a small molecule by a stimuli-responsive polymeric carrier had an enhanced effect compared to free small molecules [304, 305]. A liposomal formulation of daunorubicin and cytarabine (VYXEOS ${ }^{\circledR}$, Jazz Pharmaceuticals, Palo Alto, CA, USA) contains 100-nm-sized bilamellar liposomes, which encapsulate the two small molecule cancer therapeutics (chemotherapeutics) [302].

Nucleic acid delivery has been performed in vivo with lipid- and polymer-based carriers [9, 90, 306], but approved gene therapies deliver DNA often with viral vectors [307], non-viral carriers for DNA delivery having reached clinical trials [64, 307]. Lipid-based carriers for nucleic acids are clinically most advanced [302, 308, 309] and have been applied in vivo for siRNA [9, 310], mRNA [10-14] and DNA [311]. Clinical trials or drugs based on RNA, including approved single-stranded antisense oligonucleotides, are reviewed, for example, by Kim, Dammes and Peer, and Roberts et al. [312-314]. A comparison of the utility of DNA, RNA and proteins for carrier-mediated delivery of cargoes is given in Table 3 .

Delivery of mRNA for expressing proteins can be used to express antigens for eliciting an immune response, as known from the RNA-based coronavirus disease 2019 (COVID-19) vaccines [10-14], or it can be used with the intention to express therapeutic proteins, including antibodies $[43,315$, 316].

RNA expression levels sufficient for inducing immune responses via DCs may not be sufficient for other applications [42]. Therefore, expression levels need to be evaluated for the intended application, but were favourable in pre-clinical tests for a virus-specific mRNA-encoded antibody, which has progressed to a clinical trial. Mean systemic antibody concentrations of $3 \mu \mathrm{g} / \mathrm{ml}, 10 \mu \mathrm{g} / \mathrm{ml}$ and $78 \mu \mathrm{g} / \mathrm{ml}$ were reached in mice, and the latter two concentrations were sufficient to completely protect mice with a $100 \%$ survival rate after a lethal challenge with Chikungunya virus [60]. The feasibility of mRNA-encoded antibody therapy has been demonstrated in disease models for viral infection (rabies), toxication (botulism) and cancer (lymphoma) [43, 59]. Furthermore, if in situ expression leads to a high local concentration, the total amount of expressed antibody required for an effect may be lower, [43]. So far there are only a few pre-clinical trials and a phase I clinical trial for mRNAencoded antibodies [55, 317]. DNA-encoded antibodies have also been suggested and pursued as a therapeutic strategy [318, 319]. Advantages of delivering mRNA-encoded 
Table 3 Utility of carrier-mediated delivery of cargoes as drugs in comparison

\begin{tabular}{llll}
\hline & DNA & RNA & Proteins \\
\hline Storage stability & +++ & $-/+$ & + \\
Clinical utility & $\begin{array}{l}\text { Viral vectors have often been used for } \\
\text { approved drugs [307, 331] }\end{array}$ & $\begin{array}{c}\text { Approved drugs based on carrier-mediated } \\
\text { delivery [13,312,313] }\end{array}$ & $\begin{array}{c}\text { Less advanced } \\
\text { than nucleic acid } \\
\text { delivery }\end{array}$ \\
\hline
\end{tabular}

+++ indicates comparably high stability and tolerance towards various conditions (e.g. tolerance to high and low temperatures or to water withdrawal)

+ indicates medium stability with potential sensitivity towards several conditions including extreme temperatures or water withdrawal

$-/+$ indicates a tendency for comparably high sensitivity towards ubiquituous environmental factors often requiring freezing and storage at very low temperatures or the development of strategies to improve storage stability

antibodies compared to the administration of antibodies as proteins include the much more uniform physicochemical properties of RNA compared to proteins, making laborious optimizations of production parameters and storage buffers as required for proteins unnecessary [43]. Rapid production of RNA in large quantities is possible [43, 320, 321] without lengthy process optimizations as often required for each individual protein. Disadvantages of mRNA-encoded antibodies can be immunogenicity and activation of pattern recognition receptors and inflammatory responses, which can be desirable for vaccinations, but not for all applications of mRNA-encoded antibodies [42, 43]. Another disadvantage of RNA therapeutics compared to the administration of antibodies as proteins are effects originating from the carrier, like carrier-mediated toxicity with activation of the complement system and the risk for complement activationrelated pseudoallergy (CARPA) [43, 322].

Patisiran is an siRNA-based drug that is administered intravenously and was approved in 2018 in the USA and the EU as the first clinically approved RNAi drug [9, 302]. Patisiran is a formulation of siRNA with a lipid-based carrier composed of DLin-MC3-DMA (6Z, 9Z, 28Z, 31Z)heptatriaconta-6,9,28,31-tetraen-19-yl-4-(dimethylamino) butanoate)/DSPC (1,2-Distearoyl-sn-glycero-3-phosphocholine)/cholesterol and PEG2000-C-DMG (3-N-[( $\omega-$ methoxy poly(ethylene glycol)2000) carbamoyl]-1,2-dimyristyloxy-propylamine), see also ClinicalTrials.gov identifier: NCT01960348 and clinical study protocol ALNTTR02-004 and Assessment Report EMA/554262/2018, an ionisable lipid formulation that has been suggested to be composed of micellar structures of cationic lipids with RNA, which is eventually coated with polar lipids like PEG and phospholipids [323]. Compared to initial lipid-based carriers containing DLinDAP (1,2-dilinoleoyl-3-dimethylaminopropane), the effective dose of DLin-MC3-DMA-containing lipid-based carriers has with $0.005 \mathrm{mg} / \mathrm{kg}$ improved by more than three orders of magnitude, showing how carrier optimization allowed a remarkable improvement towards clinical utility [310, 323]. The ionisable lipid DLin-MC3-DMA is mostly uncharged at neutral $\mathrm{pH}$ and becomes cationic at low $\mathrm{pH}$, with approximately $80 \%$ of lipid being charged at endosomal pH 5.5 [123, 310]. The cationic version of ionisable lipids is thought to interact with anionic lipids of the inner part of the endosomal bilayer and disrupt the membrane after changing it from a lamellar to a hexagonal phase [324], and DLin-MC3-DMA is considered to be the key component enabling endosomal escape [123]. Patisiran is indicated for the treatment of hereditary transthyretin-mediated amyloidosis (hATTR), a disease that is characterized by the accumulation of aberrant proteins forming aggregates and destroying tissues, including that of peripheral nerves and the heart. The aggregates originate from a mutated version of a protein that is predominantly produced by the liver. Therefore, targeting of the drug to the liver is an advantage [9].

Liver targeting occurred because the lipid-based carrier adsorbs ApoE from the blood, which directs the drug to hepatocytes [313, 325]. Previous research had already found siRNA delivered by a lipid-based carrier to accumulate primarily in the liver, spleen and kidney [326]. Targeting of an siRNA drug to the liver by conjugating it to a ligand for a receptor on hepatocytes is achieved by givosiran (GIVLAARI ${ }^{\circledR}$, Alnylam Pharmaceuticals, Cambridge, MA, USA), a drug that was approved in 2019 [313]. Givosiran is an siRNA conjugated to $N$-acetylgalactosamine (GalNAc), which induces receptor-mediated internalization into hepatocytes [313].

Although naked RNA can induce an effect [42, 45], lipidbased carriers are used for the mRNA-based COVID-19 vaccines [10-14, 313]. The approved or most advanced mRNAbased COVID-19 vaccines from BioNTech, Moderna and CureVac use carriers with ionisable cationic lipids and a similar composition of helper lipids [13]. Very similar to patisiran, RNA-based COVID-19 vaccines use carriers with the formulation "ionisable cationic lipid/DSPC/cholesterol and PEG-lipid", differing in molar lipid ratios and in the exact type of ionisable cationic lipid or PEG-lipid that is used. The ionisable cationic lipid ALC-0315 (Acuitas) is used in the vaccine BNT162b2 (Comirnaty ${ }^{\circledR}$, BioNTech, 
Table 4 Examples for therapeutic application areas of approved drugs based on delivery mediated by chemical carriers

\begin{tabular}{lllll}
\hline Therapeutic area & Cargo & Carrier/delivery mediator & Drug name & References \\
\hline Hereditary disease (hATTR) & siRNA & Lipid-based & Patisiran & [9] \\
Viral infection (COVID-19 vaccine) & mRNA & Lipid-based & BNT162b2 & [11-13] \\
& & & mRNA-1273 & \\
\hline
\end{tabular}

COVID-19 coronavirus disease 2019, hATTR hereditary transthyretin-mediated amyloidosis, $m R N A$ messenger RNA, siRNA short interfering RNA

Mainz, Germany, EU/Pfizer, New York City, NY, USA), the vaccine $\mathrm{VCnCoV}$ from CureVac (Tübingen, Germany) also uses an Acuitas lipid and the vaccine mRNA-1273 (Moderna COVID-19 Vaccine ${ }^{\circledR}$, Moderna, Cambridge, MA, USA) uses SM-102 as an ionisable cationic lipid. The substances PEG-lipid ALC-0159 in BNT162b2 (2-[(polyethylene glycol)-2000]-N,N-ditetradecylacetamide, see Assessment Report EMA/707383/2020), PEG-lipid (undisclosed for VCnCoV) or PEG-DMG in mRNA-1273 (1-monomethoxypolyethyleneglycol-2,3-dimyristylglycerol with polyethylene glycol of average molecular weight 2000, see Assessment Report EMA/15689/2021) are used as helper lipids [13, 14]. Adsorption of ApoE to lipid-based carriers could potentially also play a role in targeting cell types that are relevant for vaccination, like DCs, which also highly express LDL receptors [13, 327]. Therapeutic application areas are listed in Table 4 for approved drugs based on chemical carriermediated cytosolic delivery.

\subsection{Examples for in Vivo Delivery of Protein Cargoes into the Cell}

Intracellular delivery of proteins in vivo is challenging but desirable, as efforts towards this goal indicate. Intravenous injection of lipid carriers with protein cargoes was, for example, performed in mice. Horseradish peroxidase and a variant of avidin served as model proteins. As a strategy for complexation with the lipid-based carrier, protein cargoes had been conjugated to oligonucleotides [328].

In vivo delivery of the genome editing proteins Cre and Cas9 with a lipid-based carrier has been reported [28, 329]. Negatively supercharged Cre recombinase or Cas9:sgRNA was complexed with a redox-responsive lipid via electrostatic interaction [329]. Redox-responsive properties of a carrier might facilitate release of the cargo from the carrier in the reducing environment of the cytosol [19]. Gene expression was induced after local injection of Cre/lipid complexes into the brain of a mouse line with a Cre-excisable stop-codon that prevents the expression of the fluorescent protein tdTomato. Expression of tdTomato occurred only in a very small region around the injection site in the brain, indicating very little diffusion of the injected complexes [329]. Similarly, the delivery of anionized green fluorescent protein (GFP)-Cre or Cas9:sgRNA with a lipidbased carrier to the inner ear of mice was confined to a region close to the injection site $[28,164]$. These examples demonstrate the feasibility of delivering proteins to the cytosol and nucleus in vivo. Because four Cre molecules are theoretically sufficient for recombination [148], an effect may not necessarily have required highly efficient delivery by the carrier. Because Cre alone without carrier has been reported to activate a reporter in $1.5 \%$ [48] or $17 \%$ of cells [49], the contribution of the carrier to the delivery efficiency of Cre could be questioned. However, there are also reports of experiments during which Cre was not observed to enter cells [330].

\section{Conclusion, Outlook}

Various mechanisms have been proposed over time to explain how macromolecules might reach the cytosol or nucleus of cells mediated by chemical carriers. A combination of several mechanisms is most likely responsible for successful delivery. Besides the search for the most appropriate model to describe the mechanism of delivery, the low efficiency of the delivery process mediated by chemical carriers has been repeatedly confirmed for macromolecules. Sufficient efficiency allows us to benefit from the advantages of chemical carriers compared to delivery vehicles that are more efficient but also have more drawbacks concerning safety and manufacturing. Strategies for how sufficient efficiency can be achieved in the future are outlined by which delivery approaches have been successful so far. Strategies may include engineering carriers to design delivery vehicles that are optimally tailored to enact a time- and location-controlled "delivery programme" based on detailed knowledge of molecular and cellular processes during the delivery process. Obtaining sufficient delivery efficiency may be achieved by using cargoes with a high potency to make up for the limit of the carrier for delivery efficiency. Cargoes with an inherent high potency could be chosen if possible or cargoes could be conceived to be engineered for higher potency. Selection of "productive" endocytosis pathways by avoiding uptake routes that do not contribute to endosomal escape could be a further strategy 
to enhance efficiency in the future. Another way to render delivery efficiency sufficient is the choice of highly potent processes at the organism level, which are effective even in the presence of small amounts of cargo, like the process to induce an immune response during vaccination, as demonstrated for the RNA-based COVID-19 vaccines. Eventually, all strategies combined-carriers engineered for enhanced performance, selecting potent cargoes or engineering of cargo potency, selection of endocytic uptake routes and the choice of potent processes - could be imagined to maximize an intended therapeutic effect in the future. Indeed, optimization of carriers had a substantial impact in being beneficial to the first approved siRNA drug [323]. The clinical success with nucleic acid delivery demonstrates the feasibility of cytosolic delivery in therapy. Tailoring carriers for proteins might be one way to advance protein delivery, because previous research showed nucleic acid carriers cannot easily be repurposed for proteins. With seven commercially available nucleic acid carriers, delivery efficiency for proteins was less than 5\%, and only one of 25 tested lipids efficiently delivered an antibody and beta-galactosidase into NIH3T3 cells [24]. The example of the previously hardly deliverable RNA now being used in approved drugs shows how optimization of carriers may have tremendous effects [13, 323]. Delivery of protein cargoes with chemical carriers may critically depend on the ability to cater to the physicochemical diversity of proteins, compared to nucleic acids. Attempts at engineering proteins towards more uniform cargoes have already been made, and tailoring carrier design for individual cargo properties as well as the selection of processes that are most promising to interfere with may be most relevant to advance this approach in the future. The ability to deliver proteins to the cytosol of cells could unlock a massive number of currently undruggable targets and allow interference with cellular processes in ways that are unique to proteins.

\section{Declarations}

Funding Open Access funding enabled and organized by Projekt DEAL.

Conflict of interest ALJM reports no conflicts of interest.

Availability of data and material Not applicable.

Code availability Not applicable.

Author's contributions Not applicable.

Ethics approval Not applicable.

Consent to participate Not applicable.

Consent for publication Not applicable.
Open Access This article is licensed under a Creative Commons Attribution-NonCommercial 4.0 International License, which permits any non-commercial use, sharing, adaptation, distribution and reproduction in any medium or format, as long as you give appropriate credit to the original author(s) and the source, provide a link to the Creative Commons licence, and indicate if changes were made. The images or other third party material in this article are included in the article's Creative Commons licence, unless indicated otherwise in a credit line to the material. If material is not included in the article's Creative Commons licence and your intended use is not permitted by statutory regulation or exceeds the permitted use, you will need to obtain permission directly from the copyright holder. To view a copy of this licence, visit http://creativecommons.org/licenses/by-nc/4.0/.

\section{References}

1. Stewart MP, Lorenz A, Dahlman J, Sahay G. Challenges in carrier-mediated intracellular delivery: moving beyond endosomal barriers. WIREs Nanomed Nanobiotechnol. 2016;8:465-78.

2. Stewart MP, Sharei A, Ding X, Sahay G, Langer R, Jensen KF. In vitro and ex vivo strategies for intracellular delivery. Nature. 2016;538:183-92.

3. Chabloz A, Schaefer JV, Kozieradzki I, Cronin SJF, Strebinger D, Macaluso F, et al. Salmonella-based platform for efficient delivery of functional binding proteins to the cytosol. Commun Biol. 2020;3:342.

4. Yin H, Kanasty R, Eltoukhy A, Vegas A, Dorkin R, Anderson D. Non-viral vectors for gene-based therapy. Nat Rev Genet. 2014;15:541-55.

5. Singh MS, Peer D. siRNA delivery: current trends and future perspectives. Ther Deliv. 2016;7:51-3.

6. Hobernik D, Bros M. DNA vaccines-how far from clinical use? Int J Mol Sci. 2018;19:3605.

7. Mendell JR, Al-Zaidy SA, Rodino-Klapac LR, Goodspeed K, Gray SJ, Kay CN, et al. Current clinical applications of in vivo gene therapy with AAVs. Mol Ther. 2021;29:464-88.

8. Read M, Logan A, Seymour L. Barriers to gene delivery using synthetic vectors. Adv Genet. 2005;53PA:19-46.

9. Kristen AV, Ajroud-Driss S, Conceição I, Gorevic P, Kyriakides T, Obici L. Patisiran, an RNAi therapeutic for the treatment of hereditary transthyretin-mediated amyloidosis. Neurodegener Dis Manag. 2019;9:5-23.

10. Kremsner PG, Mann P, Kroidl A et al. Safety and immunogenicity of an mRNA-lipid nanoparticle vaccine candidate against SARS-CoV-2 : A phase 1randomized clinical trial. Wien Klin Wochenschr. 2021;133(17-18):931-41.

11. Polack FP, Thomas SJ, Kitchin N, Absalon J, Gurtman A, Lockhart S, et al. Safety and efficacy of the BNT162b2 mRNA Covid19 vaccine. N Engl J Med. 2020;383:2603-15.

12. Baden LR, El Sahly HM, Essink B, Kotloff K, Frey S, Novak $\mathrm{R}$, et al. Efficacy and safety of the mRNA-1273 SARS-CoV-2 vaccine. N Engl J Med. 2021;384:403-16.

13. Verbeke R, Lentacker I, De Smedt SC, Dewitte H. The dawn of mRNA vaccines: the COVID-19 case. J Control Release Off J Control Release Soc. 2021;333:511-20.

14. Schoenmaker L, Witzigmann D, Kulkarni JA, Verbeke R, Kersten G, Jiskoot W, et al. mRNA-lipid nanoparticle COVID-19 vaccines: structure and stability. Int J Pharm. 2021;601:120586-120586.

15. Freund G, Sibler A-P, Desplancq D, Oulad-Abdelghani M, Vigneron M, Gannon J, et al. Targeting endogenous nuclear antigens by electrotransfer of monoclonal antibodies in living cells. MAbs. 2013;5:518-22. 
16. Marschall ALJ, Zhang C, Frenzel A, Schirrmann T, Hust M, Perez F, et al. Delivery of antibodies to the cytosol: debunking the myths. MAbs. 2014;6:943-56.

17. Slastnikova TA, Ulasov AV, Rosenkranz AA, Sobolev AS. Targeted intracellular delivery of antibodies: the state of the art. Front Pharmacol. 2018;9:1208.

18. Chiper M, Niederreither K, Zuber G. Transduction methods for cytosolic delivery of proteins and bioconjugates into living cells. Adv Healthc Mater. 2018;7:1701040.

19. Lee Y-W, Luther DC, Kretzmann JA, Burden A, Jeon T, Zhai $\mathrm{S}$, et al. Protein delivery into the cell cytosol using non-viral nanocarriers. Theranostics. 2019;9:3280-92.

20. Niamsuphap S, Fercher C, Kumble S, Huda P, Mahler SM, Howard CB. Targeting the undruggable: emerging technologies in antibody delivery against intracellular targets. Expert Opin Drug Deliv. 2020;17(9):1189-211.

21. Zhang C, Ötjengerdes RM, Roewe J, Mejias R, Marschall ALJ. Applying antibodies inside cells: principles and recent advances in neurobiology, Virology and Oncology. BioDrugs [Internet]. 2020. https://doi.org/10.1007/s40259-020-00419-w.

22. Verdine G, Walensky L. The challenge of drugging undruggable targets in cancer: lessons learned from targeting BCL-2 family members. Clin Cancer Res Off J Am Assoc Cancer Res. 2008;13:7264-70.

23. Mislick KA, Baldeschwieler JD. Evidence for the role of proteoglycans in cation-mediated gene transfer. Proc Natl Acad Sci USA. 1996;93:12349-54.

24. Zelphati O, Wang Y, Kitada S, Reed JC, Felgner PL, Corbeil J. Intracellular delivery of proteins with a new lipid-mediated delivery system. J Biol Chem. 2001;276:35103-10.

25. Dalkara D, Zuber G, Behr J-P. Intracytoplasmic delivery of anionic proteins. Mol Ther. 2004;9:964-9.

26. Marschall ALJ, Frenzel A, Schirrmann T, Schüngel M, Dubel S. Targeting antibodies to the cytoplasm. MAbs. 2011;3:3-16.

27. Chatin B, Mével M, Devallière J, Dallet L, Haudebourg T, Peuziat $\mathrm{P}$, et al. Liposome-based formulation for intracellular delivery of functional proteins. Mol Ther Nucleic Acids. 2015;4:e244.

28. Zuris JA, Thompson DB, Shu Y, Guilinger JP, Bessen JL, Hu $\mathrm{JH}$, et al. Cationic lipid-mediated delivery of proteins enables efficient protein-based genome editing in vitro and in vivo. Nat Biotechnol. 2015;33:73-80.

29. Liu C, Shen W, Li B, Li T, Chang H, Cheng Y. Natural polyphenols augment cytosolic protein delivery by a functional polymer. Chem Mater. 2019;31:1956-65.

30. Wang H, Wang C, Zou Y, Hu J, Li Y, Cheng Y. Natural polyphenols in drug delivery systems: current status and future challenges. Giant. 2020;3:100022.

31. Spagnou S, Miller AD, Keller M. Lipidic carriers of siRNA: differences in the formulation, cellular uptake, and delivery with plasmid DNA. Biochemistry. 2004;43:13348-56.

32. Scholz C, Wagner E. Therapeutic plasmid DNA versus siRNA delivery: common and different tasks for synthetic carriers. Drug Deliv Res Eur. 2012;161:554-65.

33. Schubert U, Traeger A, Bus T. The great escape: how cationic polyplexes overcome the endosomal barrier. J Mater Chem B. 2018;6:6904-18.

34. Zintchenko A, Philipp A, Dehshahri A, Wagner E. Simple modifications of branched PEI lead to highly efficient siRNA carriers with low toxicity. Bioconjug Chem. 2008;19:1448-55.

35. Pollard H, Toumaniantz G, Amos J, Avet-Loiseau H, Guihard $\mathrm{G}$, Behr J, et al. Ca2+-sensitive cytosolic nucleases prevent efficient delivery to the nucleus of injected plasmids. J Gene Med. 2001;3:153-64.

36. Cohen RN, van der Aa MAEM, Macaraeg N, Lee AP, Szoka FC Jr. Quantification of plasmid DNA copies in the nucleus after lipoplex and polyplex transfection. J Control Release Off J Control Release Soc. 2009;135:166-74.

37. Hansma H, Golan R, Hsieh W, Lollo C, Mullen-Ley P, Kwoh D. DNA condensation for gene therapy as monitored by atomic force microscopy. Nucleic Acids Res. 1998;26:2481-7.

38. Golan R, Pietrasanta LI, Hsieh W, Hansma HG. DNA toroids: stages in condensation. Biochemistry. 1999;38:14069-76.

39. Rejman J, Oberle V, Zuhorn IS, Hoekstra D. Size-dependent internalization of particles via the pathways of clathrin- and caveolae-mediated endocytosis. Biochem J. 2004;377:159-69.

40. Schroeder A, Levins CG, Cortez C, Langer R, Anderson DG. Lipid-based nanotherapeutics for siRNA delivery. J Intern Med. 2010;267:9-21.

41. Abdelhady H, Lin Y-L, Sun H, El-Sayed M. Visualizing the attack of RNase enzymes on dendriplexes and naked RNA using atomic force microscopy. PLoS ONE. 2013;8:e61710.

42. Sahin U, Karikó K, Türeci Ö. mRNA-based therapeuticsdeveloping a new class of drugs. Nat Rev Drug Discov. 2014;13:759-80.

43. Van Hoecke L, Roose K. How mRNA therapeutics are entering the monoclonal antibody field. J Transl Med. 2019;17:54.

44. Marschall ALJ, Dübel S, Böldicke T. Specific in vivo knockdown of protein function by intrabodies. MAbs. 2015;7:1010-35.

45. Wolff JA, Malone RW, Williams P, Chong W, Acsadi G, Jani A, et al. Direct gene transfer into mouse muscle in vivo. Science. 1990;247:1465.

46. Lorenz C, Fotin-Mleczek M, Roth G, Becker C, Dam TC, Verdurmen WPR, et al. Protein expression from exogenous mRNA: Uptake by receptor-mediated endocytosis and trafficking via the lysosomal pathway. RNA Biol. 2011;8:627-36.

47. Diken M, Kreiter S, Selmi A, Britten CM, Huber C, Türeci Ö, et al. Selective uptake of naked vaccine RNA by dendritic cells is driven by macropinocytosis and abrogated upon DC maturation. Gene Ther. 2011;18:702-8.

48. Grassman E, Klump H, Heffner N, Schwieger M, Schiedlmeier $\mathrm{B}$, Ostertag W, et al. Unmodified Cre recombinase crosses the membrane. Nucleic Acids Res. 2002;30:e59.

49. Lin Q, Jo D, Gebre-Amlak KD, Ruley HE. Enhanced cell-permeant Cre protein for site-specific recombination in cultured cells. BMC Biotechnol. 2004;4:25-25.

50. Bartlett D, Davis M. Insights into the kinetics of siRNA-mediated gene silencing from live-cell and live-animal bioluminescent imaging. Nucleic Acids Res. 2006;34:322-33.

51. Roth S, Fulcher LJ, Sapkota GP. Advances in targeted degradation of endogenous proteins. Cell Mol Life Sci CMLS. 2019;76:2761-77.

52. Cornu TI, Cathomen T. Targeted genome modifications using integrase-deficient lentiviral vectors. Mol Ther. 2007;15:2107-13.

53. Balazs AB, Chen J, Hong CM, Rao DS, Yang L, Baltimore D. Antibody-based protection against HIV infection by vectored immunoprophylaxis. Nature. 2011;481:81-4.

54. Sabnis S, Kumarasinghe ES, Salerno T, Mihai C, Ketova T, Senn JJ, et al. A novel amino lipid series for mrna delivery: improved endosomal escape and sustained pharmacology and safety in non-human primates. Mol Ther. 2018;26:1509-19.

55. Deal CE, Carfi A, Plante OJ. Advancements in mRNA encoded antibodies for passive immunotherapy. Vaccines. 2021;9:108.

56. De BP, Hackett NR, Crystal RG, Boyer JL. Rapid/sustained anti-anthrax passive immunity mediated by co-administration of Ad/AAV. Mol Ther. 2008;16:203-9.

57. Khoshnejad M, Patel A, Wojtak K, Kudchodkar SB, Humeau L, Lyssenko NN, et al. Development of novel DNA-encoded PCSK9 monoclonal antibodies as lipid-lowering therapeutics. Mol Ther. 2019;27:188-99. 
58. Pardi N, Secreto AJ, Shan X, Debonera F, Glover J, Yi Y, et al. Administration of nucleoside-modified mRNA encoding broadly neutralizing antibody protects humanized mice from HIV-1 challenge. Nat Commun. 2017;8:14630.

59. Thran M, Mukherjee J, Pönisch M, Fiedler K, Thess A, Mui BL, et al. mRNA mediates passive vaccination against infectious agents, toxins, and tumors. EMBO Mol Med. 2017;9:1434-47.

60. Kose N, Fox JM, Sapparapu G, Bombardi R, Tennekoon RN, de Silva AD, et al. A lipid-encapsulated mRNA encoding a potently neutralizing human monoclonal antibody protects against Chikungunya infection. Sci Immunol. 2019;4:eaaw6647.

61. Yamaizumi M, Mekada E, Uchida T, Okada Y. One molecule of diphtheria toxin fragment a introduced into a cell can kill the cell. Cell. 1978;15:245-50.

62. Eiklid K, Olsnes S, Pihl A. Entry of lethal doses of abrin, ricin and modeccin into the cytosol of HeLa cells. Exp Cell Res. 1980;126:321-6.

63. Schwake G, Youssef S, Kuhr J-T, Gude S, David MP, Mendoza E, et al. Predictive modeling of non-viral gene transfer. Biotechnol Bioeng. 2010;105:805-13.

64. Lächelt U, Wagner E. Nucleic acid therapeutics using polyplexes: a journey of 50 years (and Beyond). Chem Rev. 2015;115:11043-78.

65. Sgolastra F, Backlund C, Ozay EI, DeRonde B, Minter L, Tew G. Sequence segregation improves non-covalent protein delivery. J Control Release Off J Control Release Soc. 2017;254:131-6.

66. Lee K, Conboy M, Park HM, Jiang F, Kim HJ, Dewitt MA, et al. Nanoparticle delivery of Cas9 ribonucleoprotein and donor DNA in vivo induces homology-directed DNA repair. Nat Biomed Eng. 2017;1:889-901.

67. Lee B, Lee K, Panda S, Gonzales-Rojas R, Chong A, Bugay V, et al. Nanoparticle delivery of CRISPR into the brain rescues a mouse model of fragile $\mathrm{X}$ syndrome from exaggerated repetitive behaviours. Nat Biomed Eng. 2018;2:497-507.

68. Chen G, Abdeen AA, Wang Y, Shahi PK, Robertson S, Xie R, et al. A biodegradable nanocapsule delivers a Cas9 ribonucleoprotein complex for in vivo genome editing. Nat Nanotechnol. 2019;14:974-80.

69. Mout R, Ray M, Yesilbag Tonga G, Lee Y-W, Tay T, Sasaki K, et al. Direct cytosolic delivery of CRISPR/Cas9-ribonucleoprotein for efficient gene editing. ACS Nano. 2017;11:2452-8.

70. Zheng X, Lundberg M, Karlsson A, Johansson M. Lipid-mediated protein delivery of suicide nucleoside kinases. Cancer Res. 2003;63:6909.

71. Tang R, Kim CS, Solfiell DJ, Rana S, Mout R, VelázquezDelgado EM, et al. Direct delivery of functional proteins and enzymes to the cytosol using nanoparticle-stabilized nanocapsules. ACS Nano. 2013;7:6667.

72. Kim CS, Mout R, Zhao Y, Yeh Y-C, Tang R, Jeong Y, et al. Co-delivery of protein and small molecule therapeutics using nanoparticle-stabilized nanocapsules. Bioconjug Chem. 2015;26:950-4.

73. Esteban-Fernánde de Ávila B, Ramírez-Herrera DE, Campuzano S, Angsantikul P, Zhang L, Wang J. Nanomotor-enabled pH-responsive intracellular delivery of caspase-3: toward rapid cell apoptosis. ACS Nano. 2017;11:5367-74.

74. Kawasaki R, Sasaki Y, Katagiri K, Mukai S, Sawada S, Akiyoshi K. Magnetically guided protein transduction by hybrid nanogel chaperones with iron oxide nanoparticles. Angew Chem Int Ed. 2016;55:11377-81.

75. Courtête J, Sibler A-P, Zeder-Lutz G, Dalkara D, Oulad-Abdelghani M, Zuber G, et al. Suppression of cervical carcinoma cell growth by intracytoplasmic codelivery of anti-oncoprotein E6 antibody and small interfering RNA. Mol Cancer Ther. 2007;6:1728.
76. Wang S, Hüttmann G, Zhang Z, Vogel A, Birngruber R, Tangutoori $\mathrm{S}$, et al. Light-controlled delivery of monoclonal antibodies for targeted photoinactivation of Ki-67. Mol Pharm. 2015;12:3272-81.

77. Deng H, Song K, Zhao X, Li Y, Wang F, Zhang J, et al. Tumor microenvironment activated membrane fusogenic liposome with speedy antibody and doxorubicin delivery for synergistic treatment of metastatic tumors. ACS Appl Mater Interfaces. 2017;9:9315-26.

78. Molina-Crespo Á, Cadete A, Sarrio D, Gámez-Chiachio M, Martinez L, Chao K, et al. Intracellular delivery of an antibody targeting gasdermin-B reduces HER2 breast cancer aggressiveness. Clin Cancer Res. 2019;25:4846.

79. Ozay EI, Gonzalez-Perez G, Torres J, Vijayaraghavan J, Lawlor $\mathrm{R}$, Sherman $\mathrm{H}$, et al. Intracellular delivery of anti-pPKC $\theta$ (Thr538) via protein transduction domain mimics for immunomodulation. Mol Ther J Am Soc Gene Ther. 2016;24:2118-30.

80. Montero S, Seras-Franzoso J, Andrade F, Martinez-Trucharte F, Vilar-Hernández M, Quesada M, et al. Intracellular delivery of anti-SMC2 antibodies against cancer stem cells. Pharmaceutics. 2020;12:185.

81. Wang HH, Tsourkas A. Cytosolic delivery of inhibitory antibodies with cationic lipids. Proc Natl Acad Sci. 2019;116:22132.

82. Massignani M, Canton I, Patikarnmonthon N, Warren N, Armes S, Lewis A, et al. Cellular delivery of antibodies: effective targeted subcellular imaging and new therapeutic tool. Nat Preced [Internet]. 2010. https://doi.org/10.1038/npre.2010.4427.1.

83. Canton I, Massignani M, Patikarnmonthon N, Chierico L, Robertson J, Renshaw SA, et al. Fully synthetic polymer vesicles for intracellular delivery of antibodies in live cells. FASEB J. 2013;27:98-108.

84. Didenko VV, Ngo H, Baskin DS. Polyethyleneimine as a transmembrane carrier of fluorescently labeled proteins and antibodies. Anal Biochem. 2005;344:168-73.

85. Kim A, Miura Y, Ishii T, Mutaf OF, Nishiyama N, Cabral H, et al. Intracellular delivery of charge-converted monoclonal antibodies by combinatorial design of block/homo polyion complex micelles. Biomacromol. 2016;17:446-53.

86. Yamada Y, Perez SMV, Tabata M, Abe J, Yasuzaki Y, Harashima $\mathrm{H}$. Efficient and high-speed transduction of an antibody into living cells using a multifunctional nanocarrier system to control intracellular trafficking. J Pharm Sci. 2015; 104:2845-54.

87. Hasadsri L, Kreuter J, Hattori H, Iwasaki T, George JM. Functional protein delivery into neurons using polymeric nanoparticles. J Biol Chem. 2009;284:6972-81.

88. Du S, Liew SS, Zhang C, Du W, Lang W, Yao CCY, et al. Cellpermeant bioadaptors for cytosolic delivery of native antibodies: A "Mix-and-Go" approach. ACS Cent Sci [Internet]. 2020. https://doi.org/10.1021/acscentsci.0c01379.

89. Morales DP, Braun GB, Pallaoro A, Chen R, Huang X, Zasadzinski JA, et al. Targeted intracellular delivery of proteins with spatial and temporal control. Mol Pharm. 2015;12:600-9.

90. Mitchell MJ, Billingsley MM, Haley RM, Wechsler ME, Peppas NA, Langer R. Engineering precision nanoparticles for drug delivery. Nat Rev Drug Discov [Internet]. 2020. https:// doi.org/10.1038/s41573-020-0090-8.

91. Zabner J, Fasbender A, Moninger T, Egland K, Welsh M. Cellular and molecular barriers to gene transfer by a cationic lipid. J Biol Chem. 1995;270:18997-9007.

92. Onaca O, Enea R, Hughes DW, Meier W. Stimuli-responsive polymersomes as nanocarriers for drug and gene delivery. Macromol Biosci. 2009;9:129-39.

93. Pottanam Chali S, Ravoo BJ. Polymer nanocontainers for intracellular delivery. Angew Chem Int Ed. 2020;59:2962-72. 
94. Iqbal S, Blenner M, Alexander-Bryant A, Larsen J. Polymersomes for therapeutic delivery of protein and nucleic acid macromolecules: from design to therapeutic applications. Biomacromol. 2020;21:1327-50.

95. Cheng R, Meng F, Deng C, Klok H-A, Zhong Z. Dual and multi-stimuli responsive polymeric nanoparticles for programmed site-specific drug delivery. Biomaterials. 2013;34:3647-57.

96. Behr J-P. Gene transfer with synthetic cationic amphiphiles: prospects for gene therapy. Bioconjug Chem. 1994;5:382-9.

97. Rideau E, Dimova R, Schwille P, Wurm FR, Landfester K. Liposomes and polymersomes: a comparative review towards cell mimicking. Chem Soc Rev. 2018;47:8572-610.

98. Szoka F Jr, Papahadjopoulos D. Procedure for preparation of liposomes with large internal aqueous space and high capture by reverse-phase evaporation. Proc Natl Acad Sci USA. 1978;75:4194-8.

99. Gilleron J, Querbes W, Zeigerer A, Borodovsky A, Marsico G, Schubert U, et al. Image-based analysis of lipid nanoparticlemediated siRNA delivery, intracellular trafficking and endosomal escape. Nat Biotechnol. 2013;31:638-46.

100. Kulkarni JA, Witzigmann D, Leung J, Tam YYC, Cullis PR. On the role of helper lipids in lipid nanoparticle formulations of siRNA. Nanoscale. 2019;11:21733-9.

101. Schlich M, Palomba R, Costabile G, Mizrahy S, Pannuzzo M, Peer D, et al. Cytosolic delivery of nucleic acids: The case of ionizable lipid nanoparticles. Bioeng Transl Med. 2021;6:e10213.

102. Vogel AB, Kanevsky I, Che Y, Swanson KA, Muik A, Vormehr $\mathrm{M}$, et al. BNT162b vaccines protect rhesus macaques from SARS-CoV-2. Nature. 2021;592:283-9.

103. Mayer LD, Hope MJ, Cullis PR. Vesicles of variable sizes produced by a rapid extrusion procedure. Biochim Biophys Acta BBA Biomembr. 1986;858:161-8.

104. Che H, van Hest JCM. Stimuli-responsive polymersomes and nanoreactors. J Mater Chem B. 2016;4:4632-47.

105. Villegas MR, Baeza A, Vallet-Regí M. Nanotechnological strategies for protein delivery. Mol Basel Switz. 2018;23:1008.

106. Liang S-B, Liu Y, Jin X, Liu G, Wen J, Zhang L, et al. Phosphorylcholine polymer nanocapsules prolong the circulation time and reduce the immunogenicity of therapeutic proteins. Nano Res. 2016;9:1022-31.

107. Lomas H, Johnston APR, Such GK, Zhu Z, Liang K, Van Koeverden MP, et al. Polymersome-loaded capsules for controlled release of DNA. Small. 2011;7:2109-19.

108. Boussif O, Lezoualc'h F, Zanta MA, Mergny MD, Scherman D, Demeneix B, et al. A versatile vector for gene and oligonucleotide transfer into cells in culture and in vivo: polyethylenimine. Proc Natl Acad Sci USA. 1995;92:7297-301.

109. Yu H, Russ $\mathrm{V}$, Wagner E. Influence of the molecular weight of bioreducible oligoethylenimine conjugates on the polyplex transfection properties. AAPS J. 2009;11:445-55.

110. Grandinetti G, Smith AE, Reineke TM. Membrane and nuclear permeabilization by polymeric pDNA vehicles: efficient method for gene delivery or mechanism of cytotoxicity? Mol Pharm. 2012;9:523-38.

111. Bale SS, Kwon SJ, Shah DA, Banerjee A, Dordick JS, Kane RS. Nanoparticle-mediated cytoplasmic delivery of proteins to target cellular machinery. ACS Nano. 2010;4:1493-500.

112. Singh K, Ejaz W, Dutta K, Thayumanavan S. Antibody delivery for intracellular targets: emergent therapeutic potential. Bioconjug Chem. 2019;30:1028-41.

113. Kam N, Dai H. Carbon nanotubes as intracellular protein transporters: generality and biological functionality. J Am Chem Soc. 2005;127:6021-6.

114. Ghosh P, Yang X, Arvizo R, Zhu ZJ, Agasti SS, Mo Z, et al. Intracellular delivery of a membrane-impermeable enzyme in active form using functionalized gold nanoparticles. J Am Chem Soc. 2010;132:2642.

115. Scaletti F, Hardie J, Lee Y-W, Luther DC, Ray M, Rotello VM. Protein delivery into cells using inorganic nanoparticle-protein supramolecular assemblies. Chem Soc Rev. 2018;47:3421-32.

116. Ryou S-M, Yeom J-H, Kang H, Won M, Kim J-S, Lee B, et al. Gold nanoparticle-DNA aptamer composites as a universal carrier for in vivo delivery of biologically functional proteins. J Control Release. 2014; 196:287-94.

117. Méndez J, Morales Cruz M, Delgado Y, Figueroa CM, Orellano EA, Morales M, et al. Delivery of chemically glycosylated cytochrome c immobilized in mesoporous silica nanoparticles induces apoptosis in HeLa cancer cells. Mol Pharmacol. 2014;11:102.

118. Hong R, Han G, Fernández JM, Kim B, Forbes NS, Rotello VM. Glutathione-mediated delivery and release using monolayer protected nanoparticle carriers. J Am Chem Soc. 2006;128:1078-9.

119. Chiu H-Y, Deng W, Engelke H, Helma J, Leonhardt H, Bein T. Intracellular chromobody delivery by mesoporous silica nanoparticles for antigen targeting and visualization in real time. Sci Rep. 2016;6:25019.

120. Amornwachirabodee K, Tantimekin N, Pan-In P, Palaga T, Pienpinijtham P, Pipattanaboon C, et al. oxidized carbon black: preparation, characterization and application in antibody delivery across cell membrane. Sci Rep. 2018;8:2489.

121. Erbacher P, Roche AC, Monsigny M, Midoux P. Putative Role of Chloroquine in Gene Transfer into a Human Hepatoma Cell Line by DNA/Lactosylated Polylysine Complexes. Exp Cell Res. 1996;225:186-94.

122. Allen J, Najjar K, Erazo-Oliveras A, Kondow-McConaghy HM, Brock DJ, Graham K, et al. Cytosolic delivery of macromolecules in live human cells using the combined endosomal escape activities of a small molecule and cell penetrating peptides. ACS Chem Biol. 2019;14:2641-51.

123. Desai AS, Hunter MR, Kapustin AN. Using macropinocytosis for intracellular delivery of therapeutic nucleic acids to tumour cells. Philos Trans R Soc B Biol Sci. 2019;374:20180156.

124. Maina JW, Richardson JJ, Chandrawati R, Kempe K, van Koeverden MP, Caruso F. Capsosomes as long-term delivery vehicles for protein therapeutics. Langmuir. 2015;31:7776-81.

125. Kang JY, Kim S, Kim J, Kang N-G, Yang C-S, Min S-J, et al. Cell-penetrating peptide-conjugated lipid/polymer hybrid nanovesicles for endoplasmic reticulum-targeting intracellular delivery. J Mater Chem B. 2021;9:464-70.

126. Fretz M, Høgset A, Koning G, Jiskoot W, Storm G. Cytosolic delivery of liposomally targeted proteins induced by photochemical internalization. Pharm Res. 2007;24:2040-7.

127. Bonsted A, Wagner E, Prasmickaite L, HØgset A, Berg K. Photochemical enhancement of DNA delivery by EGF receptor targeted polyplexes. In: Le Doux JM, editor. Gene ther protoc des charact gene transf vectors [Internet]. Totowa: Humana Press; 2008. p. 171-81. https://doi.org/10.1007/978-1-60327-248-3_11.

128. Varkouhi AK, Scholte M, Storm G, Haisma HJ. Endosomal escape pathways for delivery of biologicals. J Control Release. 2011;151:220-8.

129. Jerjes W, Theodossiou TA, Hirschberg H, Høgset A, Weyergang A, Selbo PK, et al. Photochemical internalization for intracellular drug delivery. From basic mechanisms to clinical research. J Clin Med. 2020;9:528.

130. Berg K, Kristian Selbo P, Prasmickaite L, Tjelle TE, Sandvig $\mathrm{K}$, Moan J, et al. Photochemical internalization. Cancer Res. 1999;59:1180.

131. Muthukrishnan N, Johnson GA, Lim J, Simanek EE, Pellois J-P. TAT-mediated photochemical internalization results in cell killing by causing the release of calcium into the cytosol of cells. Biochim Biophys Acta. 2012;1820:1734-43. 
132. Muthukrishnan N, Donovan S, Pellois J-P. The photolytic activity of poly-arginine cell penetrating peptides conjugated to carboxy-tetramethylrhodamine is modulated by arginine residue content and fluorophore conjugation site. Photochem Photobiol. 2014;90:1034-42.

133. Oliveira S, Fretz MM, Høgset A, Storm G, Schiffelers RM. Photochemical internalization enhances silencing of epidermal growth factor receptor through improved endosomal escape of siRNA. Biochim Biophys Acta BBA Biomembr. 2007;1768:1211-7.

134. de Bruin KG, Fella C, Ogris M, Wagner E, Ruthardt N, Bräuchle C. Dynamics of photoinduced endosomal release of polyplexes. Fifth Int Nanomed Drug Deliv Symp. 2008;130:175-82.

135. Febvay S, Marini DM, Belcher AM, Clapham DE. Targeted cytosolic delivery of cell-impermeable compounds by nanoparticle-mediated, light-triggered endosome disruption. Nano Lett. 2010;10:2211-9.

136. Mellert K, Lamla M, Scheffzek K, Wittig R, Kaufmann D. Enhancing endosomal escape of transduced proteins by photochemical internalisation. PLoS ONE. 2012;7:e52473.

137. Mellert K, Lechner S, Lüdeke M, Lamla M, Möller P, Kemkemer $\mathrm{R}$, et al. Restoring functional neurofibromin by protein transduction. Sci Rep. 2018;8:6171.

138. Jedlitzke B, Photocaged MHD. Photocaged nanobodies delivered into cells for light activation of biological processes. ChemPhotoChem [Internet]. 2020. https://doi.org/10.1002/cptc.202000163.

139. von Gersdorff K, Sanders NN, Vandenbroucke R, De Smedt $\mathrm{SC}$, Wagner E, Ogris M. The internalization route resulting in successful gene expression depends on both cell line and polyethylenimine polyplex type. Mol Ther. 2006;14:745-53.

140. Szybalska E, Szybalski W. Genetics of human cell line. IV. DNA-mediated heritable transformation of a biochemical trait. Proc Natl Acad Sci U S A. 1962;48:2026-34.

141. Marschall ALJ, Zhang C, Dubel S. Evaluating the Delivery of Proteins to the Cytosol of Mammalian Cells. Methods Mol Biol Clifton NJ. 2017;1513:201-8.

142. Pollard H, Remy J-S, Loussouarn G, Demolombe S, Behr J-P, Escande D. Polyethylenimine but Not Cationic Lipids Promotes Transgene Delivery to the Nucleus in Mammalian Cells *. J Biol Chem. 1998;273:7507-11.

143. Matz RL, Erickson B, Vaidyanathan S, Kukowska-Latallo JF, Baker JR, Orr BG, et al. Polyplex Exposure Inhibits Cell Cycle, Increases Inflammatory Response, and Can Cause Protein Expression without Cell Division. Mol Pharm. 2013;10:1306-17.

144. Grosse S, Thévenot G, Monsigny M, Fajac I. Which mechanism for nuclear import of plasmid DNA complexed with polyethylenimine derivatives? J Gene Med. 2006;8:845-51.

145. Brunner S, Sauer T, Carotta S, Cotten M, Saltik M, Wagner E. Cell cycle dependence of gene transfer by lipoplex, polyplex and recombinant adenovirus. Gene Ther. 2000;7:401-7.

146. Lam A, Dean D, Lam AP, Dean DA. Progress and prospects: nuclear import of nonviral vectors. Gene Ther. 2010;17:439-47.

147. Lechardeur D, Sohn K-J, Haardt M, Joshi P, Monck M, Graham $\mathrm{R}$, et al. Metabolic instability of plasmid DNA in the cytosol: a potential barrier to gene transfer. Gene Ther. 1999;6:482-97.

148. Brock DJ, Kondow-McConaghy HM, Hager EC, Pellois J-P. Endosomal escape and cytosolic penetration of macromolecules mediated by synthetic delivery agents. Bioconjug Chem. 2019;30:293-304.

149. Dash PR, Toncheva V, Schacht E, Seymour LW. Synthetic polymers for vectorial delivery of DNA: characterisation of polymerDNA complexes by photon correlation spectroscopy and stability to nuclease degradation and disruption by polyanions in vitro. $\mathrm{J}$ Control Release. 1997;48:269-76.
150. Schaffer DV, Fidelman NA, Dan N, Lauffenburger DA. Vector unpacking as a potential barrier for receptor-mediated polyplex gene delivery. Biotechnol Bioeng. 2000;67:598-606.

151. Read ML, Bremner KH, Oupický D, Green NK, Searle PF, Seymour LW. Vectors based on reducible polycations facilitate intracellular release of nucleic acids. J Gene Med. 2003;5:232-45.

152. Itaka K, Harada A, Yamasaki Y, Nakamura K, Kawaguchi H, Kataoka K. In situ single cell observation by fluorescence resonance energy transfer reveals fast intra-cytoplasmic delivery and easy release of plasmid DNA complexed with linear polyethylenimine. J Gene Med. 2004;6:76-84.

153. Pei D, Buyanova M. Overcoming endosomal entrapment in drug delivery. Bioconjug Chem. 2019;30:273-83.

154. Dominska M, Dykxhoorn DM. Breaking down the barriers: siRNA delivery and endosome escape. J Cell Sci. 2010;123:1183-9.

155. Martens TF, Remaut K, Demeester J, De Smedt SC, Braeckmans $\mathrm{K}$. Intracellular delivery of nanomaterials: How to catch endosomal escape in the act. Nano Today. 2014;9:344-64.

156. Selby LI, Cortez-Jugo CM, Such GK, Johnston APR. Nanoescapology: progress toward understanding the endosomal escape of polymeric nanoparticles. WIREs Nanomed Nanobiotechnol. 2017;9:e1452.

157. Bailey A, Cullis P. Membrane fusion with cationic liposomes: effects of target membrane lipid composition. Biochemistry. 1997;36:1628-34.

158. Lu JJ, Langer R, Chen J. A novel mechanism is involved in cationic lipid-mediated functional siRNA delivery. Mol Pharm Am Chem Soc. 2009;6:763-71.

159. Yang J, Tu J, Lamers GEM, Olsthoorn RCL, Kros A. Membrane fusion mediated intracellular delivery of lipid bilayer coated mesoporous silica nanoparticles. Adv Healthc Mater. 2017;6:1700759.

160. Koltover I, Salditt T, Rädler JO, Safinya CR. An inverted hexagonal phase of cationic liposome-DNA complexes related to DNA release and delivery. Science. 1998;281:78.

161. Mizuguchi H, Nakanishi M, Nakanishi T, Nakagawa T, Nakagawa S, Mayumi T. Application of fusogenic liposomes containing fragment $\mathrm{A}$ of diphtheria toxin to cancer therapy. $\mathrm{Br} \mathrm{J}$ Cancer. 1996;73:472-6.

162. Abe A, Miyanohara A, Friedmann T. Enhanced gene transfer with fusogenic liposomes containing vesicular stomatitis virus G glycoprotein. J Virol. 1998;72:6159.

163. Yoshikawa T, Okada N, Nakagawa S. Fusogenic liposomes and their suitability for gene delivery. Future Lipidol. 2006;1:735-42.

164. Ray M, Lee Y-W, Scaletti F, Yu R, Rotello VM. Intracellular delivery of proteins by nanocarriers. Nanomed. 2017;12:941-52.

165. Jiang Y, Tang R, Duncan B, Jiang Z, Yan B, Mout R, et al. Direct cytosolic delivery of siRNA using nanoparticle-stabilized nanocapsules. Angew Chem Int Ed Engl. 2015;54:506-10.

166. Wittrup A, Ai A, Liu X, Hamar P, Trifonova R, Charisse K, et al. Visualizing lipid-formulated siRNA release from endosomes and target gene knockdown. Nat Biotechnol. 2015;33:870-6.

167. Ming X, Sato K, Juliano RL. Unconventional internalization mechanisms underlying functional delivery of antisense oligonucleotides via cationic lipoplexes and polyplexes. J Control Release Off J Control Release Soc. 2011;153:83-92.

168. Lazebnik M, Keswani RK, Pack DW. Endocytic transport of polyplex and lipoplex siRNA vectors in HeLa cells. Pharm Res. 2016;33:2999-3011.

169. Vocelle D, Chan C, Walton SP. Endocytosis controls siRNA efficiency: implications for siRNA delivery vehicle design and cell-specific targeting. Nucleic Acid Ther. 2019;30:22-32.

170. Vocelle D, Chesniak O, Malefyt A, Comiskey G, Adu-Berchie K, Smith M, et al. Dextran functionalization enhances 
nanoparticle-mediated siRNA delivery and silencing. Technology. 2016;04:42-54.

171. Huang H, Chen F-Y, Lee M-T. Molecular mechanism of peptideinduced pores in membranes. Phys Rev Lett. 2004;92:198304.

172. Prchla E, Plank C, Wagner E, Blaas D, Fuchs R. Virus-mediated release of endosomal content in vitro: different behavior of adenovirus and rhinovirus serotype 2. J Cell Biol. 1995;131:111-23.

173. Shete HK, Prabhu RH, Patravale VB. Endosomal escape: a bottleneck in intracellular delivery. J Nanosci Nanotechnol. 2014;14:460-74.

174. Vermeulen LMP, Brans T, Samal SK, Dubruel P, Demeester J, De Smedt SC, et al. Endosomal size and membrane leakiness influence proton sponge-based rupture of endosomal vesicles. ACS Nano. 2018;12:2332-45.

175. Vermeulen LMP, De Smedt SC, Remaut K, Braeckmans K. The proton sponge hypothesis: fable or fact? Eur J Pharm Biopharm. 2018;129:184-90.

176. Degors I, Wang C, Rehman ZU, Zuhorn I. Carriers break barriers in drug delivery: endocytosis and endosomal escape of gene delivery vectors. Acc Chem Res. 2019;52:1750-60.

177. Behr J-P. The proton sponge: a trick to enter cells the viruses did not exploit. Chim -ZURICH-. 1997;51:34-6.

178. Benjaminsen R, Mattebjerg M, Henriksen J, Moghimi S, Andresen T. The possible "Proton Sponge" effect of polyethylenimine (PEI) does not include change in lysosomal $\mathrm{pH}$. Mol Ther J Am Soc Gene Ther. 2012;21:149-57.

179. Rehman ZUR, Hoekstra D, Zuhorn IS. Mechanism of polyplexand lipoplex-mediated delivery of nucleic acids: real-time visualization of transient membrane destabilization without endosomal lysis. ACS Nano. 2013;7:3767-77.

180. Haensler J, Szoka FC. Polyamidoamine cascade polymers mediate efficient transfection of cells in culture. Bioconjug Chem. 1993;4:372-9.

181. van de Wetering P, Moret EE, Schuurmans-Nieuwenbroek NME, van Steenbergen MJ, Hennink WE. Structure-activity relationships of water-soluble cationic methacrylate/methacrylamide polymers for nonviral gene delivery. Bioconjug Chem. 1999;10:589-97.

182. Sonawane ND, Szoka FC Jr, Verkman AS. Chloride accumulation and swelling in endosomes enhances DNA transfer by polyamine-DNA polyplexes. J Biol Chem. 2003;278:44826-31.

183. Midoux P, Monsigny M. Efficient gene transfer by histidylated polylysine/pDNA complexes. Bioconjug Chem. 1999;10:406-11.

184. Pack DW, Putnam D, Langer R. Design of imidazole-containing endosomolytic biopolymers for gene delivery. Biotechnol Bioeng. 2000;67:217-23.

185. Akinc A, Thomas M, Klibanov AM, Langer R. Exploring polyethylenimine-mediated DNA transfection and the proton sponge hypothesis. J Gene Med. 2005;7:657-63.

186. Kichler A, Leborgne C, Coeytaux E, Danos O. Polyethylenimine-mediated gene delivery: a mechanistic study. J Gene Med. 2001;3:135-44.

187. Funhoff AM, van Nostrum CF, Koning GA, Schuurmans-Nieuwenbroek NME, Crommelin DJA, Hennink WE. Endosomal escape of polymeric gene delivery complexes is not always enhanced by polymers buffering at low $\mathrm{pH}$. Biomacromol. 2004;5:32-9.

188. Forrest ML, Meister GE, Koerber JT, Pack DW. Partial acetylation of polyethylenimine enhances in vitro gene delivery. Pharm Res. 2004;21:365-71.

189. Trützschler A-K, Bus T, Reifarth M, Brendel JC, Hoeppener S, Traeger A, et al. Beyond gene transfection with methacrylatebased polyplexes - the influence of the amino substitution pattern. Bioconjug Chem. 2018;29:2181-94.
190. Maxfield FR. Weak bases and ionophores rapidly and reversibly raise the $\mathrm{pH}$ of endocytic vesicles in cultured mouse fibroblasts. J Cell Biol. 1982;95:676-81.

191. Smith SA, Selby LI, Johnston APR, Such GK. The endosomal escape of nanoparticles: toward more efficient cellular delivery. Bioconjug Chem. 2019;30:263-72.

192. Won Y-Y, Sharma R, Konieczny SF. Missing pieces in understanding the intracellular trafficking of polycation/DNA complexes. J Control Release Off J Control Release Soc. 2009;139:88-93.

193. Merdan T, Kunath K, Fischer D, Kopecek J, Kissel T. Intracellular processing of poly(Ethylene Imine)/ribozyme complexes can be observed in living cells by using confocal laser scanning microscopy and inhibitor experiments. Pharm Res. 2002;19:140-6.

194. Hafez I, Maurer N, Cullis P. On the mechanism whereby cationic lipids promote intracellular delivery of polynucleic acids. Gene Ther. 2001;8:1188-96.

195. Hu Y, Atukorale PU, Lu JJ, Moon JJ, Um SH, Cho EC, et al. Cytosolic delivery mediated via electrostatic surface binding of protein, virus, or siRNA cargos to $\mathrm{pH}$-responsive core-shell gel particles. Biomacromol. 2009;10:756-65.

196. Tang MX, Redemann CT, Szoka FC. In vitro gene delivery by degraded polyamidoamine dendrimers. Bioconjug Chem. 1996;7:703-14.

197. Nguyen J, Szoka FC. Nucleic acid delivery: the missing pieces of the puzzle? Acc Chem Res. 2012;45:1153-62.

198. Hu Y, Litwin T, Nagaraja AR, Kwong B, Katz J, Watson N, et al. Cytosolic delivery of membrane-impermeable molecules in dendritic cells using $\mathrm{pH}$-responsive core-shell nanoparticles. Nano Lett. 2007;7:3056-64.

199. You J-O, Auguste DT. Nanocarrier cross-linking density and $\mathrm{pH}$ sensitivity regulate intracellular gene transfer. Nano Lett. 2009;9:4467-73.

200. Cupic K, Rennick J, Johnston A, Such G. Controlling endosomal escape using nanoparticle composition: current progress and future perspectives. Nanomed. 2018;14:215-23.

201. Hong S, Leroueil P, Janus E, Peters J, Kober M-M, Islam M, et al. Interaction of polycationic polymers with supported lipid bilayers and cells: nanoscale hole formation and enhanced membrane permeability. Bioconjug Chem. 2006;17:728-34.

202. Leroueil PR, Berry SA, Duthie K, Han G, Rotello VM, McNerny $\mathrm{DQ}$, et al. Wide varieties of cationic nanoparticles induce defects in supported lipid bilayers. Nano Lett. 2008;8:420-4.

203. Chen J, Hessler JA, Putchakayala K, Panama BK, Khan DP, Hong $\mathrm{S}$, et al. Cationic nanoparticles induce nanoscale disruption in living cell plasma membranes. J Phys Chem B. 2009;113:11179-85.

204. Tian W, Ma Y-Q. Insights into the endosomal escape mechanism via investigation of dendrimer-membrane interactions. Soft Matter. 2012;8:6378-84.

205. Hong S, Bielinska AU, Mecke A, Keszler B, Beals JL, Shi X, et al. Interaction of poly(amidoamine) dendrimers with supported lipid bilayers and cells: hole formation and the relation to transport. Bioconjug Chem. 2004;15:774-82.

206. Mecke A, Lee D-K, Ramamoorthy A, Orr BG, Holl MMB. Synthetic and natural polycationic polymer nanoparticles interact selectively with fluid-phase domains of DMPC lipid bilayers. Langmuir ACS J Surf Colloids. 2005;21:8588-90.

207. Leroueil PR, Hong S, Mecke A, Baker JR Jr, Orr BG, Banaszak Holl MM. Nanoparticle interaction with biological membranes: does nanotechnology present a Janus face? Acc Chem Res. 2007;40:335-42.

208. Bieber T, Meissner W, Kostin S, Niemann A, Elsasser H-P. Intracellular route and transcriptional competence 
of polyethylenimine-DNA complexes. J Control Release. 2002;82:441-54.

209. Boeckle S, von Gersdorff K, van der Piepen S, Culmsee C, Wagner E, Ogris M. Purification of polyethylenimine polyplexes highlights the role of free polycations in gene transfer. J Gene Med. 2004;6:1102-11.

210. Vaidyanathan S, Anderson KB, Merzel RL, Jacobovitz B, Kaushik MP, Kelly CN, et al. Quantitative measurement of cationic polymer vector and polymer-pDNA polyplex intercalation into the cell plasma membrane. ACS Nano. 2015;9:6097-109.

211. Xu Y, Szoka FC. Mechanism of DNA release from cationic liposome/DNA complexes used in cell transfection. Biochemistry. 1996;35:5616-23.

212. Zelphati O, Szoka FC Jr. Mechanism of oligonucleotide release from cationic liposomes. Proc Natl Acad Sci USA. 1996;93:11493-8.

213. Erazo-Oliveras A, Muthukrishnan N, Baker R, Wang T-Y, Pellois J-P. Improving the endosomal escape of cell-penetrating peptides and their cargos: strategies and challenges. Pharmaceuticals. 2012;5:1177-209.

214. Brock DJ, Kondow-McConaghy H, Allen J, Brkljača Z, Kustigian $\mathrm{L}$, Jiang M, et al. Mechanism of cell penetration by permeabilization of late endosomes: interplay between a multivalent TAT peptide and Bis(monoacylglycero)phosphate. Cell Chem Biol. 2020;27:1296-1307.e5.

215. Prevette LE, Mullen DG, Holl MMB. Polycation-induced cell membrane permeability does not enhance cellular uptake or expression efficiency of delivered DNA. Mol Pharm. 2010;7:870-83.

216. Qian Z, Martyna A, Hard RL, Wang J, Appiah-Kubi G, Coss C, et al. Discovery and mechanism of highly efficient cyclic cellpenetrating peptides. Biochemistry. 2016;55:2601-12.

217. Lomas H, Massignani M, Abdullah A, Cantón I, Presti C, Macneil S, et al. Non-cytotoxic polymer vesicles for rapid and efficient intracellular delivery. Farad Discuss. 2008;139:143-59 (discussion 213).

218. Ahmed F, Pakunlu RI, Srinivas G, Brannan A, Bates F, Klein ML, et al. Shrinkage of a rapidly growing tumor by drug-loaded polymersomes: $\mathrm{pH}$-triggered release through copolymer degradation. Mol Pharm. 2006;3:340-50.

219. Meier O, Boucke K, Hammer SV, Keller S, Stidwill RP, Hemmi $\mathrm{S}$, et al. Adenovirus triggers macropinocytosis and endosomal leakage together with its clathrin-mediated uptake. J Cell Biol. 2002;158:1119-31.

220. Lewis J, Melrose H, Bumcrot D, Hope A, Zehr C, Lincoln S, et al. In vivo silencing of alpha-synuclein using naked siRNA. Mol Neurodegener. 2008;3:19.

221. Landesman Y, Svrzikapa N, Cognetta A 3rd, Zhang X, Bettencourt BR, Kuchimanchi S, et al. In vivo quantification of formulated and chemically modified small interfering RNA by heating-in-Triton quantitative reverse transcription polymerase chain reaction (HIT qRT-PCR). Silence. 2010;1:16-16.

222. Pei Y, Hancock P, Zhang H, Bartz R, Cherrin C, Innocent N, et al. Quantitative evaluation of siRNA delivery in vivo. RNA N Y N. 2010;16:2553-63.

223. Yang NJ, Hinner MJ. Getting across the cell membrane: an overview for small molecules, peptides, and proteins. In: Gautier A, Hinner MJ, editors. Site-specif protein labeling methods protoc internet. New York: Springer, New York; 2015. p. 29-53. https:// doi.org/10.1007/978-1-4939-2272-7_3.

224. Zlokarnik G, Negulescu PA, Knapp TE, Mere L, Burres N, Feng L, et al. Quantitation of transcription and clonal selection of single living cells with $\beta$-lactamase as reporter. Science. 1998;279:84
225. Glover DJ, Leyton DL, Moseley GW, Jans DA. The efficiency of nuclear plasmid DNA delivery is a critical determinant of transgene expression at the single cell level. J Gene Med. 2010;12:77-85.

226. LaRochelle JR, Cobb GB, Steinauer A, Rhoades E, Schepartz A. Fluorescence correlation spectroscopy reveals highly efficient cytosolic delivery of certain penta-arg proteins and stapled peptides. J Am Chem Soc. 2015;137:2536-41.

227. Rezgui R, Blumer K, Yeoh-Tan G, Trexler A, Magzoub M. Precise quantification of cellular uptake of cell-penetrating peptides using fluorescence-activated cell sorting and fluorescence correlation spectroscopy. Biochim Biophys Acta BBA Biomembr. 2016;1858.

228. Mayor S, Pagano RE. Pathways of clathrin-independent endocytosis. Nat Rev Mol Cell Biol. 2007;8:603-12.

229. Hillaireau H, Couvreur P. Nanocarriers' entry into the cell: relevance to drug delivery. Cell Mol Life Sci CMLS. 2009;66:2873-96.

230. Harvey RD, Calaghan SC. Caveolae create local signalling domains through their distinct protein content, lipid profile and morphology. J Mol Cell Cardiol. 2012;52:366-75.

231. Mercer J, Helenius A. Virus entry by Macropinocytosis. Nat Cell Biol. 2009;11:510-20.

232. Gonçalves C, Mennesson E, Fuchs R, Gorvel J-P, Midoux P, Pichon C. Macropinocytosis of polyplexes and recycling of plasmid via the clathrin-dependent pathway impair the transfection efficiency of human hepatocarcinoma cells. Mol Ther. 2004;10:373-85.

233. Rejman J, Bragonzi A, Conese M. Role of clathrin- and caveolae-mediated endocytosis in gene transfer mediated by lipo- and polyplexes. Mol Ther. 2005;12:468-74.

234. van der Aa MAEM, Huth US, Häfele SY, Schubert R, Oosting RS, Mastrobattista E, et al. Cellular uptake of cationic polymerDNA complexes via caveolae plays a pivotal role in gene transfection in COS-7 cells. Pharm Res. 2007;24:1590-8.

235. Gabrielson NP, Pack DW. Efficient polyethylenimine-mediated gene delivery proceeds via a caveolar pathway in HeLa cells. J Control Release. 2009;136:54-61.

236. Billiet L, Gomez J-P, Berchel M, Jaffrès P-A, Le Gall T, Montier $\mathrm{T}$, et al. Gene transfer by chemical vectors, and endocytosis routes of polyplexes, lipoplexes and lipopolyplexes in a myoblast cell line. Biomaterials. 2012;33:2980-90.

237. Zenke M, Steinlein P, Wagner E, Cotten M, Beug H, Birnstiel ML. Receptor-mediated endocytosis of transferrin-polycation conjugates: an efficient way to introduce DNA into hematopoietic cells. Proc Natl Acad Sci USA. 1990;87:3655-9.

238. Rémy-Kristensen A, Clamme J-P, Vuilleumier C, Kuhry J-G, Mély Y. Role of endocytosis in the transfection of L929 fibroblasts by polyethylenimine/DNA complexes. Biochim Biophys Acta BBA Biomembr. 2001;1514:21-32.

239. Francis MK, Holst MR, Vidal-Quadras M, Henriksson S, Santarella-Mellwig R, Sandblad L, et al. Endocytic membrane turnover at the leading edge is driven by a transient interaction between Cdc42 and GRAF1. J Cell Sci. 2015;128:4183-95.

240. Roberts R, Al-Jamal WT, Whelband M, Thomas P, Jefferson M, van den Bossche J, et al. Autophagy and formation of tubulovesicular autophagosomes provide a barrier against nonviral gene delivery. Autophagy. 2013;9:667-82.

241. Chen X, Khambu B, Zhang H, Gao W, Li M, Chen X, et al. Autophagy induced by calcium phosphate precipitates targets damaged endosomes. J Biol Chem. 2014;289:11162-74.

242. Sahay G, Querbes W, Alabi C, Eltoukhy A, Sarkar S, Zurenko $\mathrm{C}$, et al. Efficiency of siRNA delivery by lipid nanoparticles is limited by endocytic recycling. Nat Biotechnol. 2013;31:653-8. 
243. Dahiya UR, Mishra S, Chattopadhyay S, Kumari A, Gangal A, Ganguli M. Role of cellular retention and intracellular state in controlling gene delivery efficiency of multiple nonviral carriers. ACS Omega. 2019;4:20547-57.

244. Suh J, Wirtz D, Hanes J. Efficient active transport of gene nanocarriers to the cell nucleus. Proc Natl Acad Sci. 2003;100:3878.

245. Lukacs G, Haggie P, Seksek O, Lechardeur D, Freedman N, Verkman AS. Size-dependent DNA mobility in cytoplasm and nucleus. J Biol Chem. 2000;275:1625-9.

246. Sahay G, Alakhova DY, Kabanov AV. Endocytosis of nanomedicines. J Control Release Off J Control Release Soc. 2010;145:182-95.

247. Alberts B, Johnson A, Lewis J, et al. Molecular Biology of the Cell, Introduction to Pathogens. [Internet]. 4th edition. New York: Garland Science; 2002. https://www.ncbi.nlm.nih.gov/ books/NBK26917/. Accessed 16 Oct 2021.

248. Foged C, Brodin B, Frokjaer S, Sundblad A. Particle size and surface charge affect particle uptake by human dendritic cells in an in vitro model. In: Sel Contrib 5th Eur Workshop Part Syst. 2005;298:315-22.

249. Racoosin E, Swanson J. Macropinosome maturation and fusion with tubular lysosomes in macrophages. J Cell Biol. 1993;121:1011-20.

250. Ketterer M, Shao J, Hornick D, Buscher B, Bandi V, Apicella M. Infection of primary human bronchial epithelial cells by Haemophilus influenzae: macropinocytosis as a mechanism of airway epithelial cell entry. Infect Immun. 1999;67:4161-70.

251. Lim JP, Gleeson PA. Macropinocytosis: an endocytic pathway for internalising large gulps. Immunol Cell Biol. 2011;89:836-43.

252. Hoshyar N, Gray S, Han H, Bao G. The effect of nanoparticle size on in vivo pharmacokinetics and cellular interaction. Nanomed. 2016;11:673-92.

253. Boya P, González-Polo R, Poncet D, Andreau K, Vieira H, Roumier T, et al. Mitochondrial membrane permeabilization is a critical step of lysosome-initiated apoptosis induced by hydroxychloroquine. Oncogene. 2003;22:3927-36.

254. Cirman T, Orešić K, Mazovec GD, Turk V, Reed JC, Myers RM, et al. Selective disruption of lysosomes in HeLa cells triggers apoptosis mediated by cleavage of bid by multiple papain-like lysosomal cathepsins. J Biol Chem. 2004;279:3578-87.

255. Roberg K, Kågedal K, Ollinger K. Microinjection of cathepsin d induces caspase-dependent apoptosis in fibroblasts. Am J Pathol. 2002;161:89-96.

256. Thomas TP, Majoros I, Kotlyar A, Mullen D, Holl MMB, Baker JR Jr. Cationic poly(amidoamine) dendrimer induces lysosomal apoptotic pathway at therapeutically relevant concentrations. Biomacromol. 2009;10:3207-14.

257. Yang B, Ming X, Cao C, Laing B, Yuan A, Porter M, et al. Highthroughput screening identifies small molecules that enhance the pharmacological effects of oligonucleotides. Nucleic Acids Res. 2015;43:1987-96.

258. Gilleron J, Paramasivam P, Zeigerer A, Querbes W, Marsico G, Andree C, et al. Identification of siRNA delivery enhancers by a chemical library screen. Nucleic Acids Res. 2015;43:7984-8001.

259. Rehman ZUR, Hoekstra D, Zuhorn IS. Protein kinase A inhibition modulates the intracellular routing of gene delivery vehicles in HeLa cells, leading to productive transfection. J Controlled Release. 2011;156:76-84.

260. Neuhaus B, Tosun B, Rotan O, Frede A, Westendorf A, Epple M. Nanoparticles as transfection agents: a comprehensive study with ten different cell lines. RSC Adv. 2016;6:18102-12.

261. Rennick JJ, Johnston APR, Parton RG. Key principles and methods for studying the endocytosis of biological and nanoparticle therapeutics. Nat Nanotechnol. 2021;16:266-76.
262. Nelemans LC, Gurevich L. Drug delivery with polymeric nanocarriers-cellular uptake mechanisms. Mater Basel Switz. 2020;13:366

263. Hayer A, Stoeber M, Ritz D, Engel S, Meyer HH, Helenius A. Caveolin-1 is ubiquitinated and targeted to intralumenal vesicles in endolysosomes for degradation. J Cell Biol. 2010;191:615-29.

264. Wilhelm S, Tavares AJ, Dai Q, Ohta S, Audet J, Dvorak HF, et al. Analysis of nanoparticle delivery to tumours. Nat Rev Mater. 2016;1:16014.

265. Webster R, Elliott V, Park B, Walker D, Hankin M, Taupin P. PEG and PEG conjugates toxicity: towards an understanding of the toxicity of PEG and its relevance to PEGylated biologicals. In: Veronese FM (eds). PEGylated Protein Drugs: Basic Science and Clinical Applications. Milestones in Drug Therapy. Birkhäuser Basel. 2009. https://doi.org/10.1007/978-3-7643-8679-5 8 .

266. Dölen Y, Valente M, Tagit O, Jäger E, Van Dinther EAW, van Riessen NK, et al. Nanovaccine administration route is critical to obtain pertinent iNKt cell help for robust anti-tumor T and B cell responses. Oncoimmunology. 2020;9:1738813-1738813.

267. Sonavane G, Tomoda K, Makino K. Biodistribution of colloidal gold nanoparticles after intravenous administration: Effect of particle size. Colloids Surf B Biointerfaces. 2008;66:274-80.

268. Blanco E, Shen H, Ferrari M. Principles of nanoparticle design for overcoming biological barriers to drug delivery. Nat Biotechnol. 2015;33:941-51.

269. Choi HS, Liu W, Misra P, Tanaka E, Zimmer JP, Itty Ipe B, et al. Renal clearance of quantum dots. Nat Biotechnol. 2007;25:1165-70.

270. Matsumura Y, Maeda H. A new concept for macromolecular therapeutics in cancer chemotherapy: mechanism of tumoritropic accumulation of proteins and the antitumor agent smancs a new concept for macromolecular therapeutics in cancer chemotherapy: mechanism of Tumoritropic accum. Cancer Res. 1987;46:6387-92.

271. Dai Q, Wilhelm S, Ding D, Syed AM, Sindhwani S, Zhang Y, et al. Quantifying the ligand-coated nanoparticle delivery to cancer cells in solid tumors. ACS Nano. 2018;12:8423-35.

272. Dreher MR, Liu W, Michelich CR, Dewhirst MW, Yuan F, Chilkoti A. Tumor vascular permeability, accumulation, and penetration of macromolecular drug carriers. JNCI J Natl Cancer Inst. 2006;98:335-44.

273. Nagel G, Sousa-Herves A, Wedepohl S, Calderon M. Matrix Metalloproteinase-sensitive Multistage Nanogels Promote Drug Transport in 3D Tumor Model. Theranostics. 2019;10:91-108.

274. Lu L, Li J, Moussaoui M, Boix E. Immune modulation by human secreted rnases at the extracellular space. Front Immunol. 2018;9:1012-1012.

275. Guerrini L, Alvarez-Puebla RA, Pazos-Perez N. Surface modifications of nanoparticles for stability in biological fluids. Mater Basel Switz. 2018;11:1154.

276. Ogris M, Steinlein P, Kursa M, Mechtler K, Kircheis R, Wagner E. The size of DNA/transferrin-PEI complexes is an important factor for gene expression in cultured cells. Gene Ther. 1998:5:1425-33.

277. Ogris M, Brunner S, Schüller S, Ralf K, Wagner E. PEGylated DNA/transferrin-PEI complexes: reduced interaction with blood components, extended circulation in blood and potential for systemic gene delivery. Gene Ther. 1999;6:595-605.

278. Caracciolo G, Callipo L, De Sanctis SC, Cavaliere C, Pozzi $\mathrm{D}$, Laganà A. Surface adsorption of protein corona controls the cell internalization mechanism of DC-Chol-DOPE/DNA lipoplexes in serum. Biochim Biophys Acta BBA Biomembr. 2010;1798:536-43.

279. Litzinger DC, Brown JM, Wala I, Kaufman SA, han GY, Farrell $\mathrm{CL}$, et al. Fate of cationic liposomes and their complex with 
oligonucleotive in vivo. Biochim Biophys Acta BBA Biomembr. 1996;1281:139-49.

280. Sun X, Wang G, Zhang H, Hu S, Liu X, Tang J, et al. The blood clearance kinetics and pathway of polymeric micelles in cancer drug delivery. ACS Nano. 2018;12:6179-92.

281. Fleischer CC, Payne CK. Nanoparticle-cell interactions: molecular structure of the protein corona and cellular outcomes. Acc Chem Res. 2014;47:2651-9.

282. Treuel L, Docter D, Maskos M, Stauber RH. Protein coronafrom molecular adsorption to physiological complexity. Beilstein J Nanotechnol. 2015;6:857-73.

283. Lundqvist M, Stigler J, Elia G, Lynch I, Cedervall T, Dawson KA. Nanoparticle size and surface properties determine the protein corona with possible implications for biological impacts. Proc Natl Acad Sci USA. 2008;105:14265-70.

284. Cox A, Andreozzi P, Dal Magro R, Fiordaliso F, Corbelli A, Talamini L, et al. Evolution of nanoparticle protein corona across the blood-brain barrier. ACS Nano. 2018;12:7292-300.

285. Bertrand N, Grenier P, Mahmoudi M, Lima E, Appel E, Dormont $\mathrm{F}$, et al. Mechanistic understanding of in vivo protein corona formation on polymeric nanoparticles and impact on pharmacokinetics. Nat Commun. 2017;8:777. https://doi.org/10.1038/ s41467-017-00600-w.

286. Chen D, Parayath N, Ganesh S, Wang W, Amiji M. Role of apolipoprotein- and vitronectin-enriched protein corona on lipid nanoparticles for in vivo targeted delivery and transfection of oligonucleotides in murine tumor models. Nanoscale. 2019;11:18806-24.

287. Dong Y, Love K, Dorkin R, Sirirungruang S, Zhang Y, Chen D, et al. Lipopeptide nanoparticles for potent and selective siRNA delivery in rodents and nonhuman primates. Proc Natl Acad Sci USA. 2014;111.

288. Semple SC, Chonn A, Cullis PR. Interactions of liposomes and lipid-based carrier systems with blood proteins: Relation to clearance behaviour in vivo. Interact Liposomes Serum Proteins Relat Clear. 1998;32:3-17.

289. Jenkin CR, Rowley D. The role of opsonins in the clearance of living and inert particles by cells of the reticuloendothelial system. J Exp Med. 1961;114:363-74.

290. von Roemeling C, Jiang W, Chan CK, Weissman IL, Kim BYS. Breaking down the barriers to precision cancer nanomedicine. Trends Biotechnol. 2017;35:159-71.

291. Li S, Tseng W-C, Stolz DB, Wu S-P, Watkins S, Huang L. Dynamic changes in the characteristics of cationic lipidic vectors after exposure to mouse serum: implications for intravenous lipofection. Gene Ther. 1999;6:585-94.

292. Ichihara M, Shimizu T, Imoto A, Hashiguchi Y, Uehara Y, Ishida $\mathrm{T}$, et al. Anti-PEG IgM response against PEGylated liposomes in mice and rats. Pharmaceutics. 2010;3:1-11.

293. Arvizo RR, Miranda OR, Moyano DF, Walden CA, Giri K, Bhattacharya R, et al. Modulating pharmacokinetics, tumor uptake and biodistribution by engineered nanoparticles. PLoS ONE. 2011;6:e24374-e24374.

294. Singh R, Lillard JW Jr. Nanoparticle-based targeted drug delivery. Exp Mol Pathol. 2009;86:215-23.

295. Li Y, Monteiro-Riviere NA. Mechanisms of cell uptake, inflammatory potential and protein corona effects with gold nanoparticles. Nanomed. 2016;11:3185-203.

296. Lesniak A, Fenaroli F, Monopoli MP, Åberg C, Dawson KA, Salvati A. Effects of the presence or absence of a protein corona on silica nanoparticle uptake and impact on cells. ACS Nano. 2012;6:5845-57.

297. Digiacomo L, Cardarelli F, Pozzi D, Palchetti S, Digman MA, Gratton E, et al. An apolipoprotein-enriched biomolecular corona switches the cellular uptake mechanism and trafficking pathway of lipid nanoparticles. Nanoscale. 2017;9:17254-62.

298. Song LY, Ahkong QF, Rong Q, Wang Z, Ansell S, Hope MJ, et al. Characterization of the inhibitory effect of PEG-lipid conjugates on the intracellular delivery of plasmid and antisense DNA mediated by cationic lipid liposomes. Biochim Biophys Acta BBA Biomembr. 2002;1558:1-13.

299. Walker G, Fella C, Pelisek J, Fahrmeir J, Boeckle S, Ogris $\mathrm{M}$, et al. Toward synthetic viruses: endosomal $\mathrm{pH}$-triggered deshielding of targeted polyplexes greatly enhances gene transfer and. Mol Ther J Am Soc Gene Ther. 2005;11:418-25.

300. Oupický D, Carlisle RC, Seymour LW. Triggered intracellular activation of disulfide crosslinked polyelectrolyte gene delivery complexes with extended systemic circulation in vivo. Gene Ther. 2001;8:713-24.

301. Bobo D, Robinson KJ, Islam J, Thurecht KJ, Corrie SR. Nanoparticle-based medicines: a review of FDA-approved materials and clinical trials to date. Pharm Res. 2016;33:2373-87.

302. Anselmo AC, Mitragotri S. Nanoparticles in the clinic: an update. Bioeng Transl Med. 2019;4:e10143-e10143.

303. Nanobiotix. Nanobiotix announces first ever radioenhancer to receive european market approval [Internet]. https://www.nanob iotix.com/wp-content/uploads/2019/06/PR_Nanobiotix_marqu age_CE_04042019_VF-1.pdf. Accessed 16 Oct 2021.

304. Fu Q, Xu J, Ladewig K, Henderson TMA, Qiao GG. Degradable cross-linked polymer vesicles for the efficient delivery of platinum drugs. Polym Chem. 2015;6:35-43.

305. Fenton OS, Olafson KN, Pillai PS, Mitchell MJ, Langer R. Advances in biomaterials for drug delivery. Adv Mater. 2018;30:1705328.

306. Chahal JS, Khan OF, Cooper CL, McPartlan JS, Tsosie JK, Tilley $\mathrm{LD}$, et al. Dendrimer-RNA nanoparticles generate protective immunity against lethal Ebola, H1N1 influenza, and Toxoplasma gondii challenges with a single dose. Proc Natl Acad Sci USA. 2016;113:E4133-42.

307. Keeler A, ElMallah M, Flotte T. Gene therapy 2017: progress and future directions. Clin Transl Sci. 2017;10:242-8.

308. Cullis P, Hope M. Lipid Nanoparticle Systems for Enabling Gene Therapies. Mol Ther. 2017;25:1467-75.

309. Kulkarni JA, Cullis PR, van der Meel R. Lipid nanoparticles enabling gene therapies: from concepts to clinical utility. Nucleic Acid Ther. 2018;28:146-57.

310. Jayaraman M, Ansell S, Mui B, Tam Y, Chen J, Du X, et al. Maximizing the potency of siRNA lipid nanoparticles for hepatic gene silencing in vivo. Angew Chem Int Ed Engl. 2012;51:8529-33.

311. Kulkarni JA, Myhre JL, Chen S, Tam YYC, Danescu A, Richman JM, et al. Design of lipid nanoparticles for in vitro and in vivo delivery of plasmid DNA. Nanomed Nanotechnol Biol Med. 2017;13:1377-87.

312. Kim Y-K. RNA therapy: current status and future potential. Chonnam Med J. 2020;56:87-93.

313. Dammes N, Peer D. Paving the road for RNA therapeutics. Trends Pharmacol Sci. 2020;41:755-75.

314. Roberts TC, Langer R, Wood MJA. Advances in oligonucleotide drug delivery. Nat Rev Drug Discov. 2020;19:673-94.

315. Schlake T, Thran M, Fiedler K, Heidenreich R, Petsch B, FotinMleczek M. mRNA: a novel avenue to antibody therapy? Mol Ther J Am Soc Gene Ther. 2019;27:773-84.

316. Patel A, Bah MA, Weiner DB. In vivo delivery of nucleic acidencoded monoclonal antibodies. BioDrugs. 2020;34:273-93.

317. NCT03829384. Safety, Tolerability, Pharmacokinetics, and Pharmacodynamics of mRNA-1944 in Healthy Adults, Prevention of Chikungunya Virus Infection, Phase 1 [Internet]. PPD Phase 1 Clinical Research Unit, Austin, Texas,; [cited 2021 Jun 4]. https://ClinicalTrials.gov/show/NCT03829384 
318. Muthumani K, Block P, Flingai S, Nagarajan M, Chaitanya I, Tingey C, et al. Rapid and long-term immunity elicited by dnaencoded antibody prophylaxis and DNA vaccination against Chikungunya virus. J Infect Dis. 2016;214:jiw111.

319. Andrews CD, Huang Y, Ho DD, Liberatore RA. In vivo expressed biologics for infectious disease prophylaxis: rapid delivery of DNA-based antiviral antibodies. Emerg Microbes Infect. 2020;9:1523-33.

320. Pardi N, Muramatsu H, Weissman D, Karikó K. In vitro transcription of long RNA containing modified nucleosides. Methods Mol Biol Clifton NJ. 2013;969:29-42.

321. Weissman D, Pardi N, Muramatsu H, Karikó K. HPLC purification of in vitro transcribed long RNA. Methods Mol Biol Clifton NJ. 2013;969:43-54

322. Szebeni J, Fontana JL, Wassef NM, Mongan PD, Morse DS, Dobbins DE, et al. Hemodynamic changes induced by liposomes and liposome-encapsulated hemoglobin in pigs. Circulation. 1999;99:2302-9.

323. Kulkarni JA, Witzigmann D, Chen S, Cullis PR, van der Meel R. Lipid nanoparticle technology for clinical translation of siRNA therapeutics. Acc Chem Res. 2019;52:2435-44.

324. Semple S, Akinc A, Chen J, Sandhu A, Mui B, Cho C, et al. Rational design of cationic lipids for siRNA delivery. Nat Biotechnol. 2010;28:172-6.

325. Akinc A, Querbes W, De S, Qin J, Frank-Kamenetsky M, Jayaprakash K, et al. Targeted delivery of RNAi therapeutics with endogenous and exogenous ligand-based mechanisms. Mol Ther J Am Soc Gene Ther. 2010;18:1357-64.

326. Shi B, Keough E, Matter A, Leander K, Young S, Carlini E, et al. Biodistribution of small interfering RNA at the organ and cellular levels after lipid nanoparticle-mediated delivery. J Histochem Cytochem Off J Histochem Soc. 2011;59:727-40.

327. van den Elzen P, Garg S, León L, Brigl M, Leadbetter EA, Gumperz JE, et al. Apolipoprotein-mediated pathways of lipid antigen presentation. Nature. 2005;437:906-10.

328. Eltoukhy AA, Chen D, Veiseh O, Pelet JM, Yin H, Dong Y, et al. Nucleic acid-mediated intracellular protein delivery by lipid-like nanoparticles. Biomaterials. 2014;35:6454-61.

329. Wang M, Zuris JA, Meng F, Rees H, Sun S, Deng P, et al. Efficient delivery of genome-editing proteins using bioreducible lipid nanoparticles. Proc Natl Acad Sci. 2016;113:2868.

330. Wadia JS, Stan RV, Dowdy SF. Transducible TAT-HA fusogenic peptide enhances escape of TAT-fusion proteins after lipid raft macropinocytosis. Nat Med. 2004;10:310.

331. Shahryari A, Saghaeian Jazi M, Mohammadi S, Razavi Nikoo H, Nazari Z, Hosseini ES, et al. Development and clinical translation of approved gene therapy products for genetic disorders. Front Genet. 2019;10:868-868. 